\title{
Olivine Positive Electrodes for Li-Ion Batteries: Status and Perspectives
}

\author{
Alain Mauger and Christian M. Julien * \\ Sorbonne Université, Campus Pierre et Marie Curie, Institut de Minéralogie, de Physique des Matériaux et de \\ Cosmochimie (IMPMC), CNRS UMR 7590, 4 place Jussieu, 75005 Paris, France; alain.mauger@upmc.fr \\ * Correspondence: christian.julien@upmc.fr
}

Received: 18 July 2018; Accepted: 14 August 2018; Published: 17 August 2018

\begin{abstract}
Among the compounds of the olivine family, $\mathrm{Li} \mathrm{MPO}_{4}$ with $M=\mathrm{Fe}, \mathrm{Mn}, \mathrm{Ni}$, or Co, only $\mathrm{LiFePO}_{4}$ is currently used as the active element of positive electrodes in lithium-ion batteries. However, intensive research devoted to other elements of the family has recently been successful in significantly improving their electrochemical performance, so that some of them are now promising for application in the battery industry and outperform $\mathrm{LiFePO}_{4}$ in terms of energy density, a key parameter for use in electric vehicles in particular. The purpose of this review is to acknowledge the current state of the art and the progress that has been made recently on all the elements of the family and their solid solutions. We also discuss the results from the perspective of their potential application in the industry of Li-ion batteries.
\end{abstract}

Keywords: olivines; cathodes; lithium-ion batteries

\section{Introduction}

The olivine-based positive electrode (cathode) materials have been extensively studied (see [1] for a review). $\mathrm{LiFePO}_{4}$ (LFP) is now a worldwide commercial product as an active element of cathodes for lithium batteries. Cheaper, safer, and less toxic than $\mathrm{LiCoO}_{2}$ and other lamellar compounds with cobalt in their chemical formula, LFP-based lithium batteries are currently the best choice for large-scale applications [2]. LFP has become a reference cathode, associated with different anodes in full electrochemical cells [3]. We have discussed elsewhere the superiority of LFP among lithium-ion batteries in terms of thermal stability and safety, an issue which is critical for HEV and EV applications, and a fortiori in planes. This has been confirmed experimentally by battery fires experienced in electric cars and planes equipped with batteries containing cathode materials with two-dimensional structure [4]. To summarize in a few lines the 200 pages (pp. 119-319) of Ref. [2] we have devoted to a comparative study of the different cathodes for Li-ion batteries (LIBs), let us recall that olivines also avoid the problem of aging of batteries equipped with manganese spinels due to the dissolution of $\mathrm{Mn}^{3+}$ in the electrolyte, which still limits their calendar life. The problem was partly solved by surface modifications, but they increase the price of the powder, and they did not permit the stabilizing of the cycle life over thousands of cycles, while a battery without significant fade after more than 1100 cycles (three years, if charged once per day) is a basic requirement. Non-spinel manganese dioxides have a tendency to transform irreversibly to a spinel-like structure upon cycling, and none of the fluoro-polyionic compounds are competitive. Many efforts are currently being devoted to investigating other technologies. They have been put into perspective with olivines in previous reviews [5,6]. We have reported elsewhere a prospect of these technologies including Li-S [7], $\mathrm{Na}-, \mathrm{Mg}-$, $\mathrm{Al}-$, and K-ion batteries [8]. We have discussed the place of lithium batteries among other technologies for energy storage in Ref. [9]. From these considerations, we concluded that the future of lithium batteries is bright for the next years to come, thus confirming the interest in the olivine compounds. 
The main disadvantage of olivines with respect to other cathode chemistries for lithium batteries is the lower energy density. This is evidenced in Table 1 where we have reported the gravimetric and volumetric energy densities of LFP and two other cathode materials which have also found a market place in commercial batteries for electric vehicles: the manganese spinel $\mathrm{LiMn}_{2} \mathrm{O}_{4}$, and " $\mathrm{LiNiCoAl}$ " (NCA). In terms of energy density, the winner is clearly NCA, the cathode material used by Panasonic to manufacture the batteries of Tesla cars. However, the low energy density of LFP was not an obstacle for its success for EV applications. The top-selling EV manufacturer in the world today is BYD, which makes its own batteries. Its success comes from its choice of the LFP cathode chemistry. As an example, BYD's LFP battery used by e6 taxis in Shenzen has a driving range of $200 \mathrm{~km}$ and can be charged to $80 \%$ in just $20 \mathrm{~min}$, or $100 \%$ in only $40 \mathrm{~min}$ using a BYD DC fast charger. The town has 12,000 taxis which will be electric by the end of this year, and all of the 7,000,000 buses are already electric buses, $80 \%$ being BYD buses.

Table 1. Characteristics of active cathode materials currently used in batteries that equip electric vehicles. The specific capacities and energy densities are the theoretical values.

\begin{tabular}{|c|c|c|c|c|}
\hline Cathode & $\begin{array}{l}\text { Density } \\
\left(\mathrm{g} \mathrm{cm}^{-3}\right)\end{array}$ & $\begin{array}{l}\text { Specific Capacity } \\
\quad\left(\mathrm{mAh} \mathrm{g}^{-1}\right)\end{array}$ & $\begin{array}{l}\text { Specific Energy } \\
\quad\left(\mathrm{Wh}^{-1}\right)\end{array}$ & $\begin{array}{l}\text { Energy Density } \\
\left(\mathrm{kWh} \mathrm{L} \mathrm{L}^{-1}\right)\end{array}$ \\
\hline $\mathrm{LiFePO}_{4}$ & 3.60 & 169 & 0.59 & 2.10 \\
\hline $\mathrm{LiFePO}_{4}+5 \% \mathrm{C}$ & 3.48 & 159 & 0.56 & 1.95 \\
\hline $\mathrm{LiMn}_{2} \mathrm{O}_{4}$ & 4.3 & 148 & 0.56 & 2.40 \\
\hline $\mathrm{LiNi}_{0.8} \mathrm{Co}_{0.15} \mathrm{Al}_{0.05} \mathrm{O}_{2}$ & 4.85 & 274 & 0.98 & 4.75 \\
\hline
\end{tabular}

Although efforts have still been made to optimize LFP in recent years, many efforts have been focused on the electrochemical properties of the other isomorphous elements of the olivine family- $\mathrm{LiMPO}$, with $M=\mathrm{Mn}, \mathrm{Co}, \mathrm{Ni}$, and their combination-aiming to increase the energy density with respect to $\mathrm{LiFePO}_{4}$, since their increasing redox potential $M^{3+} / \mathrm{M}^{2+} \mathrm{vs} \mathrm{Li}^{+} / \mathrm{Li}$ increases along this series. It was demonstrated that the redox energies of transition metal ions depend on the inductive effect induced by the counter cations [10]. The shifts in the redox potentials can be understood in terms of covalency changes of the $M-\mathrm{O}$ bonds and $M-\mathrm{O}-M$ interactions [11]. The different positions of the $\mathrm{M}^{2+/ 3+}$ redox energy are shown in Figure 1, which displays the specific capacity/discharge potential profiles of olivine frameworks in lithium cells. The progress that has been made in recent years was the motivation for the present review. The results are discussed and put in perspective in terms of the competition for the next generation of lithium batteries.

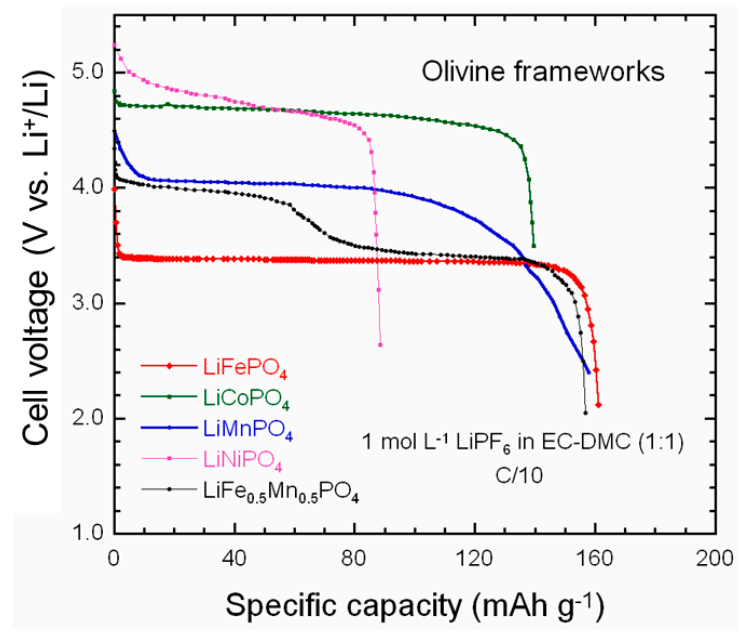

Figure 1. Discharge profiles of $\mathrm{LiMPO}_{4}(M=\mathrm{Fe}, \mathrm{Mn}, \mathrm{Ni}, \mathrm{Co})$ olivines and $\mathrm{LiFe}{ }_{0.5} \mathrm{Mn}_{0.5} \mathrm{PO}_{4}$ solid solution as cathodes of Li-ion batteries. Voltages were measured in half cells versus lithium metal. 


\section{2. $\mathrm{LiFePO}_{4}$}

$\mathrm{LiFePO}_{4}$ (LFP) has a flat charge-discharge profile at $3.45 \mathrm{~V}$ versus $\mathrm{Li}^{+} / \mathrm{Li}$. This flatness makes determining the state of charge (SOC) more difficult, but increasingly accurate algorithms are available to determine this parameter in commercial use $[12,13]$. The experimental capacity that can be reached since some years ago is close to the theoretical one $\left(170 \mathrm{mAh} \mathrm{g}^{-1}\right)$, owing to the coating of the particles by a thin (typically $2 \mathrm{~nm}$ thick) layer of conductive carbon. Owing to the $\mathrm{Fe}-\mathrm{C}$ affinity, many carbonaceous materials can be used as the carbon precursor, provided that it is an organic compound since the presence of hydrogen is needed to reduce iron and avoid the formation of impurities containing iron in the $\mathrm{Fe}^{3+}$ valence state. A monosaccharide such as glucose or fructose is often chosen because it generates a porous carbon coating, which facilitates the penetration of the electrolyte, but a disaccharide such as lactose that contains a glucose molecule bound to a galactose molecule works as well [14]. On another hand, calcination from a macromolecular compound containing a benzene ring, such as phenol-formaldehyde (P-F) resin, forms a denser carbon coating, which improves the electrical conductivity but makes the penetration of the electrolyte more difficult. Therefore, an optimum choice is a mixture of both types of precursors. A mixed carbon source of $30 \%$ P-F and $70 \%$ sucrose was proposed as the optimum composition [15]. Recently, beta-cyclodextrin, an oligosaccharide encompassing seven glucoses in a ring structure, was also successful [16].

Since LFP has poor electronic conductivity, this carbon coating is essential to obtaining good electrochemical properties. Usually, the mass of the carbon coating is included in the given specific capacity, for the simple reason that the synthesis of the material and the carbon coating is a one-step process, so that the weight of the powder measured after the synthesis includes the weight of the carbon coating. The mass of the carbon coating depends on the size of the particles. For a $2 \mathrm{~nm}$ thick carbon layer, the carbon coating represents only $1 \mathrm{wt} \%$ for a monodisperse powder with particle size of $1 \mu \mathrm{m}$, but $14 \mathrm{wt} \%$ if the particle size is $50 \mathrm{~nm}$. That is why we have reported in Table 1 the characteristics of the LFP powder with an intermediate value of $5 \mathrm{wt} \%$ carbon. Recent works have still been devoted to its optimization through different processes, such as in situ carbon coating by a hydrothermal process [17] and use of graphene as the building block and sucrose as a linker [18]. Advanced carbon materials in LFP composites are highly graphitized carbon and have been reviewed in Ref. [19]. The role of surfactants, which affect the particle size and the amount of graphite-like carbons of $\mathrm{LiFePO}_{4} / \mathrm{C}$ composites, has been studied by different authors [20,21]. In particular, Bazzi et al. [20] showed that increasing the length of the alkyl chain of surfactants decreases the particle size, which is beneficial to the electrochemical properties, but also decreases the amount of graphitic-like carbon, which is damageable. Therefore, an optimization was found with a composite surfactant mixing long and short lengths of alkyl chains, leading to capacities of $167 \mathrm{mAh} \mathrm{g}^{-1}$ at $0.1 \mathrm{C}$ rate and $129 \mathrm{mAh}$ $\mathrm{g}^{-1}$ at $5 \mathrm{C}$ rate, which are a few $\mathrm{mAh}^{-1}$ larger than for LFP coated with polyaniline-poly(ethylene glycol) (PANI-PEG) prepared by an in situ copolymerization method [22]. Nevertheless, the use of only one of these surfactants (Tween-80) was sufficient to synthesize via a hydrothermal process LFP/C particles $100 \mathrm{~nm}$ in thickness, which delivered a capacity of $166 \mathrm{mAh} \mathrm{g}^{-1}$ at $0.1 \mathrm{C}$ and $119 \mathrm{mAh} \mathrm{g}^{-1}$ at $20 \mathrm{C}$ [23]. The conductivity of the carbon coating is limited by the sintering temperature used during the synthesis, which cannot exceed $700{ }^{\circ} \mathrm{C}$ in order to avoid the formation of impurities. However, the electrical conductivity of the carbon, and, thus, of the powder, can be increased by doping the carbon by nitrogen. Recently, N-doped carbon-coated LFP nanospheres synthesized by a hydrothermal plus chemical polymerization method used as an electrode delivered $158 \mathrm{mAh} \mathrm{g}^{-1}$ after 200 cycles at $1 \mathrm{C}$ and good rate capability (107 $\mathrm{mAh} \mathrm{g}^{-1}$ at $\left.30 \mathrm{C}\right)$ [24], as can be seen in Figure 2. 

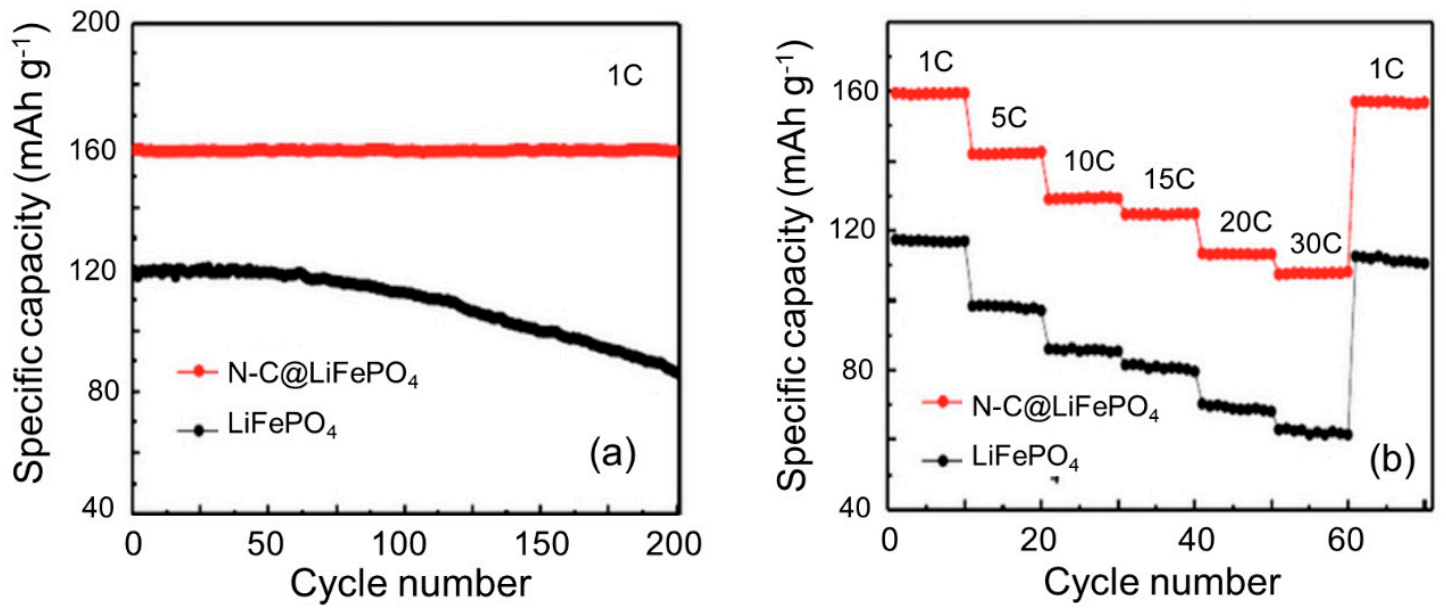

Figure 2. Electrochemical performance of $\mathrm{LiFePO}_{4}$ (LFP) coated with N-doped carbon (N-C@LFP) and noncoated LFP nanospheres tested at $25^{\circ} \mathrm{C}$. (a) Cycling performance at $1 \mathrm{C}$. (b) Rate performance from $1 \mathrm{C}$ to $30 \mathrm{C}$. Reproduced from [24].

\subsection{Morphology}

The performance of LFP also depends on the morphology, which can appear under different forms depending on the synthesis conditions when, in particular, the material is prepared by solvothermal or hydrothermal processes [25]. Very good results were obtained with spherical morphology by using 3D coralloid nitrogen-containing carbon as an interpenetrating conductive framework [26], microspheres consisting of nanofibers [27], dumbbell-shaped mesocrystals consisting of self-assembly $\mathrm{LiFePO}_{4}$ nanorods each with 2-3 $\mu \mathrm{m}$ in length and 30-50 $\mathrm{nm}$ in diameter [28], bow-tie-like nanocrystals [29], hollow nanoparticles [30], nanoplates, and nanorods [31]. In this last case, the discharge capacity was $155 \mathrm{mAh} \mathrm{g}^{-1}$ at $0.5 \mathrm{C}$ and $124 \mathrm{mAh} \mathrm{g}^{-1}$ at $5 \mathrm{C}$. In a different work, $\mathrm{LiFePO}_{4} / \mathrm{C}$ nanorods including $9 \mathrm{wt} \%$ carbon delivered a discharge capacity of $120 \mathrm{mAh} \mathrm{g}^{-1}$ at $10 \mathrm{C}$ rate with $83 \%$ capacity retention after 2000 cycles [32]. In this later case, the LFP/C material was prepared by a solvothermal route. Owing to the beneficial effect of surfactant in increasing the graphitization degree of the carbon and the nanorod morphology, LFP/C nanorods hydrothermally synthesized using tetraglycol as surfactant, with $10 \mathrm{wt} \%$ conductive additive, delivered a capacity of $160 \mathrm{mAh} \mathrm{g}^{-1}$ at $0.1 \mathrm{C}$, and, most of all, a capacity of $55 \mathrm{mAh} \mathrm{g}^{-1}$ at $200 \mathrm{C}$ was obtained, which amounts to a power density of $95 \mathrm{~kW} \mathrm{~g}^{-1}$ [33]. The capacity retention was also very good (92\% discharge capacity retention after 200 cycles at $100 \mathrm{C}$ ). An LFP nanonetwork consisting of interconnected $\sim 10 \mathrm{~nm}$ sized carbon-coated particles obtained by a sol-gel-based synthesis procedure, which utilizes a block copolymer (BCP) as a templating agent and a homopolymer as an additional carbon source, displayed a high rate of performance (120 mAh g $\mathrm{m}^{-1}$ at $20 \mathrm{C})$ and an excellent cycle life [34].

Electrospinning was proposed to grow LFP/C nanofibers [35-40]. In Ref. [37], the nanofibers were obtained by using polyacrylonitrile (PAN) as an electrospinning media and a carbon source. They delivered a capacity of $162 \mathrm{mAh} \mathrm{g}^{-1}$ at $0.1 \mathrm{C}$ rate and $139 \mathrm{mAh} \mathrm{g}^{-1}$ at $1 \mathrm{C}$, owing to the large surface-to-volume ratio offered by such a morphology. This result is significantly better than the results reported for the other electrospun LFP/C nanofibers. Note that the amount of carbon in the carbon coating is usually larger than $10 \mathrm{wt} \%$ for such nanofibers, and the electrospinning technique is not yet competitive with other more traditional techniques used for the synthesis of LFP/C. Better results were actually obtained with LFP (001) nanorods obtained by a conventional hydrothermal process, followed by carbon coating with sucrose as the precursor. Such LFP/C nanorods delivered a capacity of $173 \mathrm{mAh} \mathrm{g}^{-1}$ at $0.1 \mathrm{C}, 117 \mathrm{mAh} \mathrm{g}^{-1}$ at $10 \mathrm{C}$, and the capacity after 500 cycles at $10 \mathrm{C}$ was still $113 \mathrm{mAh} \mathrm{g}^{-1}$, which corresponds to $96.5 \%$ capacity retention [41]. This remarkable result is due to the reduction of the lithium path along the (010) direction, known to be the preference for Li transport. 
Solvothermally synthesized LFP/C nanopillows with ethylene glycol as reaction medium solvent showed even better rate capability, with a capacity of $112 \mathrm{mAh} \mathrm{g}^{-1}$ at $30 \mathrm{C}$ [42], presumably because of the reduced size of the particles $(100 \mathrm{~nm})$, which is an important parameter in obtaining good rate capability [43]. This result is a major improvement with respect to prior results on LFP nanoplates also obtained by a solvothermal process $\left(46 \mathrm{mAh} \mathrm{g}^{-1}\right.$ at $30 \mathrm{C}$ ) [44-46]. However, as noticed by the authors in [43], with a view to the economic cost, there are much greater prospects for realizing practical application of the LFP/C nanorods, at least when the nanorods can be synthesized at a growth rate fast enough to facilitate industrial production.

Actually, the results reported above mainly concern lab-scale syntheses and electrochemical performance. Since, however, LFP is commercial product, we found it desirable to report on the synthesis routes used for LFP available on the market (typical characteristics of commercial LFP powders will be reported in Section 2.7). Advances and challenges in LIB materials for automotive applications, in particular with respect to cost and industrial synthesis processes, have been published recently [47]. In the particular case of LFP, the industrial processes that are currently used are the hydrothermal and solid-state routes. Typical hydrothermal syntheses are performed at high pressures and are energy intensive compared with solid-state reactions, making them more expensive. However, Benedek et al. recently found a low-temperature hydrothermal process which reduces the energy required for the synthesis by $30 \%$, making the energy consumption comparable to that of solid-state reaction [48]. The discharge capacity of the LFP product was maintained at $150 \mathrm{mAh} \mathrm{g}^{-1}$, so this synthesis process is promising for industrial processing, with the advantage that the hydrothermal synthesis enables particle size and shape control not available with the solid-state approach.

\subsection{LFP/Graphene Composites}

Since coating the particles with a highly graphitic type of carbon is difficult, it might seem simpler to just prepare an LFP/graphene composite, and many works have been published on such a composite [49-58]. The difficulty in that case is to disperse the graphene; otherwise, the improvement of the rate capability is limited [59]. LFP/G prepared by solvothermal processes [60] and hydrothermal processes [61] delivered capacities of 90 and $98 \mathrm{mAh} \mathrm{g}^{-1}$, respectively, at a $10 \mathrm{C}$ rate. This capacity raised to $109 \mathrm{mAh}^{-1}$ with LFP/G prepared by chemical vapor deposition [62]. The best results, however, were obtained with composites prepared by solid-state reaction, which delivered $116 \mathrm{mAh} \mathrm{g}^{-1}$ at a $10 \mathrm{C}$ rate [63] but the capacity retention has not been tested. On another hand, $119 \mathrm{mAh} \mathrm{g}^{-1}$ at $10 \mathrm{C}$ rate with capacity decay rate of $2.3 \%$ after 120 cycles was achieved for LFP/graphene/carbon composite synthesized from $\mathrm{FePO}_{4} \cdot 2 \mathrm{H}_{2} \mathrm{O} /$ graphene oxide [64]. Note, however, that better rate capabilities have been obtained without graphene, since the hollow $\mathrm{LiFePO}_{4}$ nanoparticles synthesized by solvothermal processing using ammonium tartrate as an additive delivered a capacity of $121 \mathrm{mAh} \mathrm{g}^{-1}$ at $10 \mathrm{C}$ along with good cycling performance [30]. In this case, the electrode was prepared from a mixture of LFP, graphite, and polyvinylidene fluoride (PVdF) binder in the weight ratio 8:1:1. Also, LFP/C nanopillows prepared by a solvothermal method in ethylene glycol delivered a discharge capacity of $112 \mathrm{mAh} \mathrm{g}^{-1}$ at $30 \mathrm{C}$ [42]. In this case, the electrode was obtained by mixing these LFP particles with acetylene black and PVDF in the weight ratio 75:15:10. Therefore, even though mass production of graphene for industrial applications is progressing fast, its use in LFP-based lithium batteries is not guaranteed. However, in this competition to obtain the best electrochemical performance, $\mathrm{LFP} /$ graphene has recovered an advantage with recent results. $\mathrm{LiFePO}_{4}$ nanoplatelets with highly oriented (010) facets in situ grown on graphene sheets cross-linked to form a three-dimensional (3D) porous network displayed the same initial capacity of $121 \mathrm{mAh} \mathrm{g}^{-1}$ at $10 \mathrm{C}$, with an improved $98 \%$ capacity retention over 1000 cycles at this high charge rate [65] (see Figure 3). In this case, the weight fraction of graphene was $8.63 \mathrm{wt} \%$. Recently, graphene-decorated carbon-coated $\mathrm{LiFePO}_{4}$ nanospheres, with approximately $3 \mathrm{wt} \%$ graphene, delivered capacities of 164 and $147 \mathrm{mAh} \mathrm{g}^{-1}$ at $0.1 \mathrm{C}$ and $1 \mathrm{C}$, respectively, and the capacity was retained at $81 \mathrm{mAh} \mathrm{g}^{-1}$ at $20 \mathrm{C}$. The composites revealed $8 \%$ capacity decay at $10 \mathrm{C}$ after 500 cycles [66]. At $0.1 \mathrm{C}, 1 \mathrm{C}$, and $10 \mathrm{C}$, well-dispersed 
LFP nanoparticles anchored on a 3D graphene aerogel displayed specific discharge capacities of 167, 153, and $120 \mathrm{mAh}^{-1}$, respectively [67], higher than 3D porous LFP/graphite composite (134 and $48 \mathrm{mAh} \mathrm{g}^{-1}$ ) [68], graphene nanoribbon-wrapped LFP (152 and $103 \mathrm{mAh} \mathrm{g}^{-1}$ ) [69], and 3D amorphous carbon and graphene co-modified LFP (163 and $90 \mathrm{mAh} \mathrm{g}^{-1}$ ) [70].
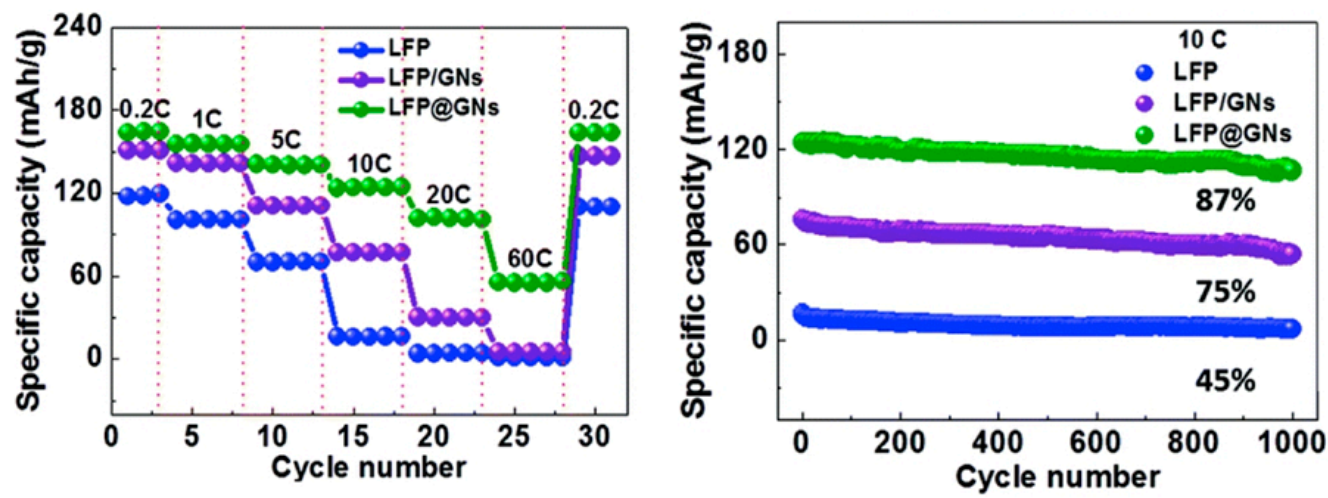

Figure 3. (Left) Rate capabilities from $0.2 \mathrm{C}$ to $60 \mathrm{C}$. (Right) Long-term cycling stabilities at a $10 \mathrm{C}$ rate of $\mathrm{LiFePO}_{4}(\mathrm{LFP}), \mathrm{LiFePO}_{4}$ ex situ modified with graphene $\mathrm{LFP} / \mathrm{GNs}$, and $\mathrm{LiFePO}_{4}$ nanoplatelets grown in situ on graphene sheets with highly oriented (010) facets of $\mathrm{LiFePO}_{4}$ (LFP@GNs). Reproduced from [65].

Note that we have considered in the present work only results obtained with composites in which the amount of graphene in the electrode was limited to the few wt \% requested by the battery industry. Of course, a larger amount of graphene will still increase the rate capability, but then the electrochemical properties are those of supercapacitors, as the increase of the power density is at the expense of the energy density. For instance, an LFP electrode with $30 \mathrm{wt} \%$ graphene displayed a capacity retention higher than $80 \%$ after 1000 cycles at $30 \mathrm{C}$ [71]. From a practical perspective, such LFP/C composites can be considered as supercapacitors with a specific capacitance of $200 \mathrm{~F} \mathrm{~g}^{-1}$ [72].

It is also possible to mix graphene with other conductive forms of carbon. LFP coated with three carbon sources (viz., graphene oxide, thermoplastic phenolic resin, and water-soluble starch) playing different roles in constructing the hierarchical conductive architecture delivered a capacity of $120 \mathrm{mAh} \mathrm{g}^{-1}$ at $10 \mathrm{C}$, but the capacity retention was not good [73]. The performance of LFP-based electrodes can be improved by combining the positive effects of graphene and carbon nanotubes. In particular, a nanocrystalline $\mathrm{LiFePO}_{4} /$ grapheme-carbon nanotubes (LFP-G-CNT) composite exhibited a high initial discharge capacity of $168 \mathrm{mAh} \mathrm{g}^{-1}$ at $0.1 \mathrm{C}$ and $104 \mathrm{mAh} \mathrm{g}^{-1}$ at $40 \mathrm{C}$ and an excellent cycling stability, superior to the performance of LFP-G and LFP-CNT [74].

Other forms of carbon entering the composite have also been successful. LFP nanocrystals grown in situ on interconnected carbon nanotubes/mesoporous carbon nanosheets (designated as LFP@CNTs/CNSs) delivered a capacity of $122 \mathrm{mAh} \mathrm{g}^{-1}$ at $10 \mathrm{C}$ with an outstanding capacity retention of $90 \%$ over 1000 cycles [75].

\subsection{Tap Density}

Another parameter that plays an important role in the performance of LFP is the tap density. Decreasing the size of the particles increases the effective surface area between LFP and the electrolyte, which is beneficial to the mass energy density, but also results in a decrease of the tap density and, thus, the volumetric energy density. A compromise can be found in the synthesis of LFP/C powder made of secondary micro- or sub-micro-sized particles consisting of nanosized primary particles. This configuration can be obtained by the dissolution-precipitation process that governs crystal growth [76,77]. In addition to this morphology allowing a tap density of $1.2 \mathrm{~g} \mathrm{~cm}^{-3}$, the porosity of the particles increases the effective surface area. As a result, the capacity reached $\sim 40 \mathrm{mAh} \mathrm{g}^{-1}$ at $1 \mathrm{C}$, with $100 \%$ capacity retention over the 50 cycles tested [78]. LFP/C with the same hierarchical structure 
(micro-sized spherical primary particles made of secondary particles (10-50 nm in thickness)) delivered a capacity of $161 \mathrm{mAhg}^{-1}$ at $0.1 \mathrm{C}$ and $106 \mathrm{mAhg}^{-1}$ at $20 \mathrm{C}$ with very good capacity retention over the 80 cycles tested [79]. A tap density of $1.3 \mathrm{~g} \mathrm{~cm}^{-3}$ was recorded recently for $\mathrm{LiFePO}_{4} / \mathrm{C}$ microspheres with diameters of 5-10 $\mu \mathrm{m}$ aggregated by enormous nanoplates [16], but the capacity retention and rate capability were smaller than the results reported in this review, presumably because the size of the particles was too big.

\subsection{Doping}

Due to the one-dimensional motion of $\mathrm{Li}^{+}$ions in LFP, the electrochemical properties are very sensitive to any defect that can block the lithium channels (see Section 2.5). A recent example is Al, which also blocks Li channels [80]. There have been many attempts to substitute Fe with an aliovalent ion, but this is a difficult task because such a doping is not energetically favorable and the unbreakable $\mathrm{PO}_{4}{ }^{3-}$ bonding prevents charge balance by oxygen-vacancy formation [81-83]. The case of vanadium, however, is an exception. The insertion of $V$ has been debated for some time, but it is now recognized that $\mathrm{V}$ substitutes for $\mathrm{Fe}$ with $\mathrm{V}$ in the $\mathrm{V}^{3+}$ valence state, with a charge compensation due to $\mathrm{Fe}$ vacancies, to form $\mathrm{LiFe}_{1-3 \mathrm{y} / 2} \mathrm{~V}_{\mathrm{y}} \mathrm{PO}_{4}$, or, equivalently $\mathrm{LiFe}_{1-3 \mathrm{y} / 2} \mathrm{~V}_{\mathrm{y}} \square_{\mathrm{y} / 2} \mathrm{PO}_{4}$, where $\square$ means an Fe vacancy, up to a limit of solubility of $10 \mathrm{~mol} \%$ vanadium $[84,85]$. This formula is that of the V-doped LFP at open-circuit voltage and has been simplified as it omits the lithium vacancies also introduced by the V-doping. However, more recent experiments discussed in the following sections on V-doped $\mathrm{LiMn}_{0.8} \mathrm{Fe}_{0.2} \mathrm{PO}_{4}$ [86] show that the lithium vacancies can be filled with lithium in a half-cell where the $\mathrm{Li}$ anode is a reservoir of $\mathrm{Li}^{+}$ions, converting $\mathrm{V}^{3+}$ into $\mathrm{V}^{2+}$ during the discharge below the redox potential $\mathrm{V}^{3+} / \mathrm{V}^{2+}$ of $2.6 \mathrm{~V}$ versus $\mathrm{Li}^{+} / \mathrm{Li}$. This result should also apply to V-LFP, so that $\mathrm{V}-\mathrm{LiFePO}_{4}$, like $\mathrm{V}-\mathrm{Li}(\mathrm{Fe}, \mathrm{Mn}) \mathrm{PO}_{4}$, can be obtained with $\mathrm{V}$ in the $\mathrm{V}^{2+}$ valence state after discharge, in which case $\mathrm{V}$ is not an aliovalent ion. Aliovalent or not, the insertion of $\mathrm{V}$ in LFP improves the electrical conductivity and, thus, the electrochemical performance of LFP [87]. Various hypotheses have been invoked which have been reviewed, for instance, in Ref. [86], but contrary to prior claims, this increase of conductivity is intrinsic in nature due to the increase of the lithium diffusion coefficient associated with the insertion of vanadium [86].

\subsection{Impurities and Defects}

The electrochemical properties of LFP are very sensitive to the conditions of preparation. In particular, a deficiency of lithium in the precursors results in the formation of an antisite defect with Fe occupying a Li site in the lattice. These defects block the lithium channels and thus importantly damage the electrochemical properties [88]. We have also shown that heating LFP above $700{ }^{\circ} \mathrm{C}$ results in the formation of $\mathrm{Fe}_{2} \mathrm{P}$ nanoparticles at the surface of the particles. Since $\mathrm{Fe}_{2} \mathrm{P}$ is a metal, it plays a role similar to that of the carbon coating, and it is thus beneficial to the electrochemical performance in the short term. However, the effect in the long term is quite different. The carbon coating does not affect the calendar life of the cells. To the contrary, iron in $\mathrm{Fe}_{2} \mathrm{P}$ dissolves into the electrolyte, which importantly reduces the life of the cells. Although we have repeatedly mentioned it in many publications [89-93], there are still some works that claim a beneficial effect of the formation of $\mathrm{Fe}_{2} \mathrm{P}$ with the argument that it increases the capacity rate capability [94]. Again, we warn the reader that this is actually a bad idea. Surface modification of LFP with Sn nanoparticles [95] will have the same beneficial effect on the capacity and rate capability, without reducing the calendar life.

\subsection{Structural Changes during Cycling}

LFP is the only olivine compound that operates at a very high C-rate over thousands of cycles [96]. Elucidating the high rate mechanism is of high technological interest. At thermodynamic equilibrium, the material is a two-phase system with phase separation between heterosite $\mathrm{Li}_{0.04} \mathrm{FePO}_{4}$ and olivine $\mathrm{Li}_{0.96} \mathrm{FePO}_{4}$ [97]. This phase separation has been observed experimentally even in particles as small as $50 \mathrm{~nm}$ [98]. However, under very high C-rate conditions, thermodynamic equilibrium cannot 
be reached, and different studies have been devoted to the investigation of the structural changes resulting from the deviation from equilibrium. A theoretical model predicted the formation of a full solid solution at high overpotential [99]. By analysis of in situ X-ray diffraction experiments, Liu et al. found that metastable lithium concentrations in $\mathrm{Li}_{x} \mathrm{FePO}_{4}$ can be achieved when charging at a $10 \mathrm{C}$ rate [100]. The experiments, however, did not permit knowledge of whether these concentrations were located near the interface between the Li-rich and the Li-poor phases, or if they were attributable to a homogeneous solid solution. The answer has been given recently owing to the high-rate delithiation reaction of $\mathrm{LiFePO}_{4}$ with the gaseous oxidant $\mathrm{NO}_{2}$, whose reaction free energy corresponds to a charge at about $4.1 \mathrm{~V}$ versus $\mathrm{Li} / \mathrm{Li}^{+}$[101]. Kuss et al. observed the structural changes through in situ synchrotron X-ray diffraction and electronic changes through in situ UV/vis reflectance spectroscopy during the delithiation of $\mathrm{LiFePO}_{4}$ by this process at high rates, reaching a $100 \%$ state of charge in $10 \mathrm{~s}$ [102]. The results showed unambiguously that the olivine and heterosite phases still existed, and the phase separation between them macroscopically persists, with a widened solid solution only located along the interface.

\subsection{Characteristic Properties of Commercial LFP}

The particle size of commercial LFP used in batteries ranges from tens of nanometers to a few microns. For instance, TMAX Battery Equipments sells different LFP powders with particle sizes 0.55, 1.5 , and 6 microns, with tap density $1.13 \mathrm{~g} \mathrm{~cm}^{-3}$. On another hand, the LFP powder of A123 18650 LFP cells has an average particle size $62.5 \mathrm{~nm} \pm 20 \mathrm{~nm}$ (tap density not reported). The cycle life of this commercial cell (number of cycles before the cell reaches $80 \%$ of its initial capacity, which is the usual definition for EV applications) is 2500 cycles under normal conditions (100\% SOC and 100\% DOD) at $1 \mathrm{C}$ rate [103]. Note that the limitation came from the graphite anode, not the cathode. This cell weighs $39 \mathrm{~g}$ and its capacity is $1.1 \mathrm{Ah}$, so its energy density is $88 \mathrm{Wh} \mathrm{kg}^{-1}$. This is smaller than the performance of the 18650-type cell commercialized by K2 Energy, which has almost the same weight, $39.5 \mathrm{~g}$, but a capacity raised to $1.5 \mathrm{Ah}$ and an energy density of $121 \mathrm{Wh} \mathrm{kg}^{-1}$, also featuring more than 2000 cycles according to the specifications of the manufacturer. The difference between the two cells might be explained by the bigger size of the C-LFP powder used by K2 Energy, so that the weight of the carbon coating would be reduced and the tap density would be increased, as we have recalled above. This, however, remains a hypothesis, since the characteristics of the powder used by K2 Energy are unknown. For comparison, the Panasonic NCA-cell (NCR18650A) used by Tesla has a twice-larger capacity of $3.1 \mathrm{Ah}$ and weighs $45.5 \mathrm{~g}$. The drawback is a reduced cycle life: According to the data sheet [104], $80 \%$ of the initial capacity is obtained after nearly 250 cycles at charge at $0.3 \mathrm{C}$, discharge at $1 \mathrm{C}$, and charge/discharge rest: $20 \mathrm{mn}$. A cycle life of $>1000$ cycles for this cell can be recovered only for slow discharge rates C/3 [105].

\section{3. $\mathrm{LiMnPO}_{4}$}

With respect to $\mathrm{LiFePO}_{4}, \mathrm{LiMnPO}_{4}(\mathrm{LMP})$ has the same theoretical capacity as $\mathrm{LiFePO}_{4}$, but it has the advantage of a higher redox potential of $4.1 \mathrm{~V}$ for $\mathrm{Mn}^{2+} / \mathrm{Mn}^{3+}$ versus $\mathrm{Li}^{+} / \mathrm{Li}$, so that its theoretical energy density is $697 \mathrm{Wh} \mathrm{kg}^{-1}$ (see Figure 1 and Table 1 for comparison). However, LMP also presents disadvantages. First, its electrical conductivity is even smaller than that of LFP by 5 orders of magnitude [106], which results in a lower rate capability. Second, $\mathrm{Mn}^{3+}$ is a Jahn-Teller (JT) ion, and the JT distortion is responsible for important strains and an energy barrier at the $\mathrm{LiMnPO} \mathrm{P}_{4} / \mathrm{MnPO}_{4}$ interface [107]. In the case of LFP, carbon coating of the nanoparticles solved the problem of the low conductivity. This coating, however, is more difficult in the case of $\mathrm{LiMnPO}_{4}$ mainly because the strong $\mathrm{Fe}-\mathrm{C}$ interaction that made the carbon coating of LFP very easy is lost when Fe is replaced by $\mathrm{Mn}$. In addition, the diffusion coefficient of the lithium is small, unless the temperature rises to $70{ }^{\circ} \mathrm{C}$ [108]. However, at such a high temperature, the usual electrolytes degrade not only because of the carbonates, but also due to the poor stability of the $\mathrm{LiPF}_{6}$ salt; finally, the dissolution of the $\mathrm{Mn}^{2+}$ in the electrolyte accelerates at this temperature, thus reducing the life of the battery. Therefore, 
it is difficult to use LMP-based Li-ion batteries at such temperatures, and its use in Li-metal polymer batteries is not possible at the present time because one would have to find a polymer that is both compatible with lithium and resists at operating potential larger than $4.0 \mathrm{~V}$.

Due to the very poor electronic conductivity of LMP, reasonable capacities have been obtained only for particles of size smaller than $50 \mathrm{~nm}$ to minimize the travel of the electrons inside the particles during cycling, and only when the particles are carbon-coated. The simple mixing of the particles with additive carbon, as obtained after ball-milling, is not sufficient [44]. Once the electrons reach the carbon layer at the surface, they are driven to the current collector by the carbon, provided that the carbon percolates through the structure. Such particles of different morphologies were synthesized by the different processes used for all the olivine compounds, reviewed in Ref. [1]. The different processes include solid-state reaction [109], spray pyrolysis plus ball milling [110], hydrothermal processing [111], synthesis in a chloride/ethylene glycol-based deep eutectic solvent [112], and microwave heating in a deep eutectic solvent [113]. In principle, all these processes can be used. However, in the case when ball milling is used, the milling induces amorphization of the surface layer, so that annealing to recrystallize this layer is needed [114]. Meanwhile, ball milling is used to increase the loading in the electrode. With this process, the volumetric density of $263 \mathrm{mAh} \mathrm{cm}^{-3}$ was obtained, which is ca. 3.5 times higher than the one obtained by hand-mixing [115]. The materials thus prepared were able to deliver a capacity larger than $100 \mathrm{mAh} \mathrm{g}^{-1}$. For instance, we note that $110 \mathrm{mAh} \mathrm{g}^{-1}$ at a $1 \mathrm{C}$ rate was reached with $30 \mathrm{~nm}$ thick C-coated LMP prepared by the polyol route [116,117]. More recently, LMP particles with a flaky morphology synthesized by the microwave-assisted polyol route delivered a capacity of $126 \mathrm{mAh} \mathrm{g}^{-1}$ with a capacity retention ratio of $\sim 99.9 \%$ after 50 cycles at $1 \mathrm{C}$ [118]. A capacity of $120 \mathrm{mAh} \mathrm{g}^{-1}$ at $1 \mathrm{C}$ rate was reported for carbon-coated nanorods [119]. Discharge capacities in the range 130-140 $\mathrm{mAh}^{-1}$ were reported when the particles are immersed in a huge quantity of conductive carbon (30 wt \% [111,120] or $20 \mathrm{wt} \%$ [121]). However, the amount of carbon in commercial cathodes is limited to few wt \%, and such large amounts of carbon importantly reduce the volume energy density of the electrode. A high initial capacity of $160 \mathrm{mAh} \mathrm{g}^{-1}$ was achieved with C-LMP nanoplates with a thickness of $50 \mathrm{~nm}$ prepared via a sol-gel route [109]. At a $1 \mathrm{C}$ charge/discharge rate, a specific capacity of $54 \mathrm{mAh} \mathrm{g}^{-1}$ was delivered, but $117 \mathrm{mAh} \mathrm{g}^{-1}$ was attained at the $1 \mathrm{C}$ discharge rate after charging at $\mathrm{C} / 25$. However, $20 \mathrm{wt} \%$ carbon was still used in the cathode. The main efforts should then be focused on the possibility of achieving high capacities and a good rate capability with LMP particles using a smaller amount of carbon.

\subsection{Carbon Coating}

The conductivity of the carbon coating increases with the temperature of the deposit [122]. However, increasing this temperature too much will lead to the formation of impurities, so a compromise has to be found. In the case of LFP, this is $650-700{ }^{\circ} \mathrm{C}$ [14]. This is also the case for $\mathrm{LiMnPO}_{4}$. The main difference between LMP and LFP is in the choice of the carbon precursor. In practice, any type of carbon precursor can be chosen with little impact on the electrochemical performance in the case of C-LFP, owing to the affinity of iron for carbon. The only restriction is that the carbon source must also contain hydrogen which plays the role of reducing agent [123]. In practice, lactose, sugar, or glucose are chosen. In the case of LMP, however, the electrochemical properties are sensitive to the choice of the precursor [124,125]. In Ref. [124], this effect was attributed to the graphitization degree of the carbon layer depending on the precursor. On the other hand, Li et al. [125] showed that this dependence was attributable to whether or not carbon was uniformly coated on the surface, based on high-resolution transmission electron microscope (HRTEM) images and electrochemical impedance spectroscopy (EIS) measurements. Indeed, the graphitization degree, measured from the analysis of the Raman spectra, did not significantly depend on the choice of the precursor. The different precursors they have tested are beta-cyclodextrin, ascorbic acid, citric acid, glucose, and sucrose to coat LMP nanorods prepared by the solvothermal route. The carbon coating was obtained by calcination at $700{ }^{\circ} \mathrm{C}$ for $5 \mathrm{~h}$ under a $\mathrm{N}_{2}+7 \% \mathrm{H}_{2}$ atmosphere. The electrode was 
a mixture of C-LMP nanorods, acetylene black, and PVdF in N-methylpyrrolidinone at a weight ratio of 75:15:1. Good results were obtained with beta-cyclodextrin, in which case capacities of 153, 143, 90, and $57 \mathrm{mAh} \mathrm{g}^{-1}$ were reached at $0.1 \mathrm{C}, 0.2 \mathrm{C}, 2 \mathrm{C}$ and 5 C, respectively, stable over the 50 cycles tested. Using oleylamine in the synthesis process as both solvent and carbon source, C-LMP was obtained with particle size smaller than $40 \mathrm{~nm}$ and with uniform carbon coating of 2-3 nm. Used as a cathode, the product delivered a capacity of $168 \mathrm{mAh} \mathrm{g}^{-1}$ at $0.1 \mathrm{C}$ and $105 \mathrm{mAh} \mathrm{g}^{-1}$ at $5 \mathrm{C}$. At $1 \mathrm{C}$, the initial capacity was $135 \mathrm{mAh} \mathrm{g}^{-1}$ with, however, a capacity retention of $81 \%$ at the 50th cycle [126]. These results were actually an improvement with respect to prior reports on C-LMP prepared by high-energy milling [127], solid-state reaction [128], microwave heating [129] (capacity of

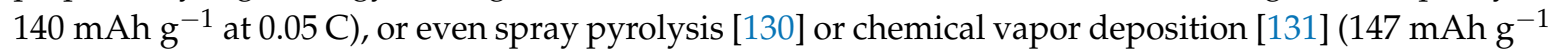
at $0.05 \mathrm{C}$ in both cases). Since then, better rate capabilities have been obtained with almost spherical C-LMP particles of very small size (8-12 $\mathrm{nm}$ ) by a solvothermal method using sucrose as the carbon precursor [132]. The electrode was prepared with PVdF as the binder and Timcal Super P carbon black in the gravimetric ratio 7:1:2. The capacity at low C-rates was comparable to the result reported in Ref. [125], but the capacity at larger C-rates was improved, remaining at $130 \mathrm{mAh} \mathrm{g}^{-1}$ at the 35th cycle at $0.5 \mathrm{C}$, owing to the very small size of the particles. Note that the electrolyte included propylene carbonate (PC), which is a very good conductor and is thus quite appropriate to the test with a lithium metal counter-electrode. However, PC cannot be used with graphite (see, for instance, a review on salts and solvents [8]); in such a case, the usual carbonates such as ethylene carbonate (EC) and diethyl carbonate (DEC) that are less conducting should be used, which will reduce the rate capability. Nevertheless, the result is remarkable.

\subsection{Particle Size}

This result also illustrates the interest in preparing LMP particles with very small size. Several methods can be used to reach this goal: using phosphate-formate precursor [133], ultrasonic spray pyrolysis [110], antisolvent precipitation [134], and hydrothermal processes [135]. LMP/C nanorods (thickness less than $50 \mathrm{~nm}$ ) successfully prepared via a solvothermal approach in a mixed solvent of ethylene glycol and water delivered a capacity of $168 \mathrm{mAh} \mathrm{g}^{-1}$ and $110 \mathrm{mAh} \mathrm{g}^{-1}$ at $0.05 \mathrm{C}$ and $10 \mathrm{C}$, respectively, and a capacity retention of $94.5 \%$ after 100 cycles at $0.5 \mathrm{C}$ [136].

However, some obstacles hinder the commercialization of nanoparticles for reasons already mentioned in the section devoted to LFP. First, such nano-sized particles are difficult to handle [137]. Second, they limit the tap density to low values $\left(0.3-0.8 \mathrm{~g} \mathrm{~cm}^{-3}\right)$, which reduces the volumetric energy density of the product [138]. Like in the case of LFP, the solution was to use hierarchical structures. The combination of nano-sized crystallites (20-50 nm) forming micron-sized secondary particles was obtained by a mechano-chemical liquid-phase activation technique and gave good results [139]. Comparable capacities with improved rate capability were obtained with such a combination of nano primary particles and micron-sized secondary particles in $\mathrm{Li}(\mathrm{Mn}, \mathrm{Fe}) \mathrm{PO}_{4}$ as we shall see, which confirms the efficiency of this combination that optimizes the tap density.

\subsection{Cycle Life}

Although the energy density, the rate capability, and capacity delivered by LMP have increased significantly in recent years, the cycle life remains a problem. We can invoke the stress-strains due to the volume change and the JT distortion due to $\mathrm{Mn}^{3+}$ during cycling. The solid-state diffusion of lithium is also a cause of mechanical degradation [140], although this last cause is not specific to LMP. Usually, the results on LMP-based cells in the literature are reported for over 100 cycles at best. The degradation mechanism has been investigated by several authors [141,142] and results from several phenomena. First, the Jahn-Teller distortion due to $\mathrm{Mn}^{3+}$ creates a stress-strain field which damages the structure of the material. A post-mortem analysis has shown the amorphization of LMP upon cycling, which corroborates this cause of ageing [142]. Another problem met with any manganese compound used as the active element of a cathode is the dissolution of $\mathrm{Mn}^{2+}$ in the electrolyte. In the particular 
case of LMP, such a dissolution has been evidenced by the formation of $\mathrm{Li}_{4} \mathrm{P}_{2} \mathrm{O}_{7}$ at the surface of LMP [141]. In addition, electrolyte oxidation processes on carbon black have been observed at high voltages [143]. This effect, which is not observed with LFP working at lower potential, reduces the electrical conductivity of the carbon and may create ionic and electrical barriers at the interface between the carbon and the LMP particles. This difficulty, however, can seemingly be overcome owing to a cross-linking of $\mathrm{Li}_{2} \mathrm{TiO}_{3}$ with carbon, making possible the co-coating of LMP primary particles $(30-50 \mathrm{~nm})$ by $\mathrm{Li}_{2} \mathrm{TiO}_{3}$ and carbon distributed uniformly in the thicknesses of 2.2 and $1.2 \mathrm{~nm}$, respectively [144] (see Figure 4). The electrode composed of $3 \mathrm{wt} \% \mathrm{C} / \mathrm{Li}_{2} \mathrm{TiO}_{3}$-coated LMP particles with carbon black and PVdF in the ratio 70:20:10 delivered capacities of 132 and $118 \mathrm{mAh} \mathrm{g}^{-1}$ at $0.5 \mathrm{C}$ and $2 \mathrm{C}$, respectively, with a capacity retention of $93 \%$ after 240 cycles at $2 \mathrm{C}$ with the standard electrolyte ( $1 \mathrm{~mol} \mathrm{~L}^{-1} \mathrm{LiPF}_{6}$ in a 1:1 mixture of EC/DMC). This capacity retention is an improvement, but still not sufficient to open the route of commercial use. Also, the protection of $\mathrm{Li}_{2} \mathrm{TiO}_{3}$ coating against $\mathrm{Mn}$ dissolution is not complete: after 3 weeks, the concentration of Mn dissolved in the electrolyte was 70 ppm (against 220 ppm without the $\mathrm{Li}_{2} \mathrm{TiO}_{3}$ coating), which will still limit the calendar life.
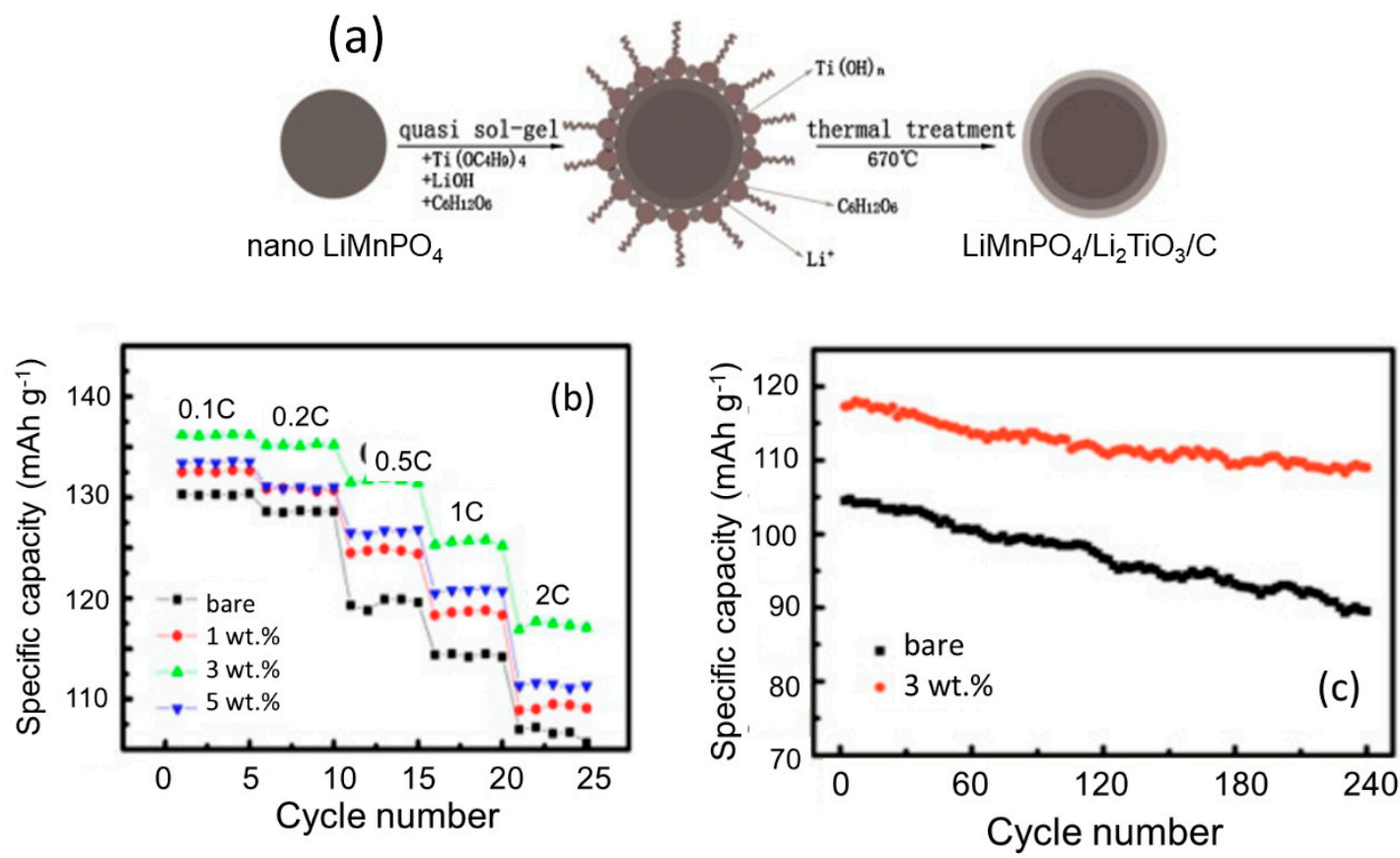

Figure 4. (a) Two-step approach for co-coating of $\mathrm{Li}_{2} \mathrm{TiO}_{3}$ (LTO) and carbon on the surface of nano $\mathrm{LiMnPO}_{4}$. (b) Rate performance of LMP/LTO/C with various amounts $x\left(0,1 \%, 3 \%, 5 \mathrm{wt} \% \mathrm{Li}_{2} \mathrm{TiO}_{3}\right.$ to $\mathrm{LiMnPO}_{4}$ ). (c) Cycle performance of bare and $3 \mathrm{wt} \% \mathrm{Li}_{2} \mathrm{TiO}_{3}$-coated $\mathrm{LiMnPO}_{4}$ samples at $2.0 \mathrm{C}$. Reproduced from [144].

In a different geometry, nest-like $\mathrm{LiMnPO}_{4}$ microstructures with a diameter of ca. 6-9 $\mu \mathrm{m}$ and a thickness of ca. 4-7 $\mu \mathrm{m}$ constructed by many loose nanosheets with a thickness of ca. $30 \mathrm{~nm}$ displayed capacities of 158 and $137 \mathrm{mAh} \mathrm{g}^{-1}$ at 0.5 and $5 \mathrm{C}$ rates, respectively, and good capacity retention of $93 \%$ over 100 cycles [145] (see Figure 5). Note the Raman spectra show that the carbon coating is graphitic and, thus, very conductive, which may explain the very good capability. The carbon coating was obtained by the chemical vapor deposition technique using toluene as the carbon source. Another reason that can be invoked is the porosity, which enhances the effective surface in contact with the electrolyte and is thus beneficial to the electrochemical properties, provided that the side-reactions at the solid electrolyte interphase (SEI) are controlled [146]. Alternate nanosheet/nanoparticle sandwich carbon-coated LMP particles of size as small as $20 \mathrm{~nm}$-important to avoid the agglomeration of the nanosheets-delivered $165 \mathrm{mAh} \mathrm{g}^{-1}$ at $0.05 \mathrm{C}$ and $142.5 \mathrm{mAh} \mathrm{g}^{-1}$ at $0.2 \mathrm{C}$ with, however, 
limited capacity retention upon cycling [147]. Nevertheless, this capacity is better than the prior results obtained with LMP nanosheets.
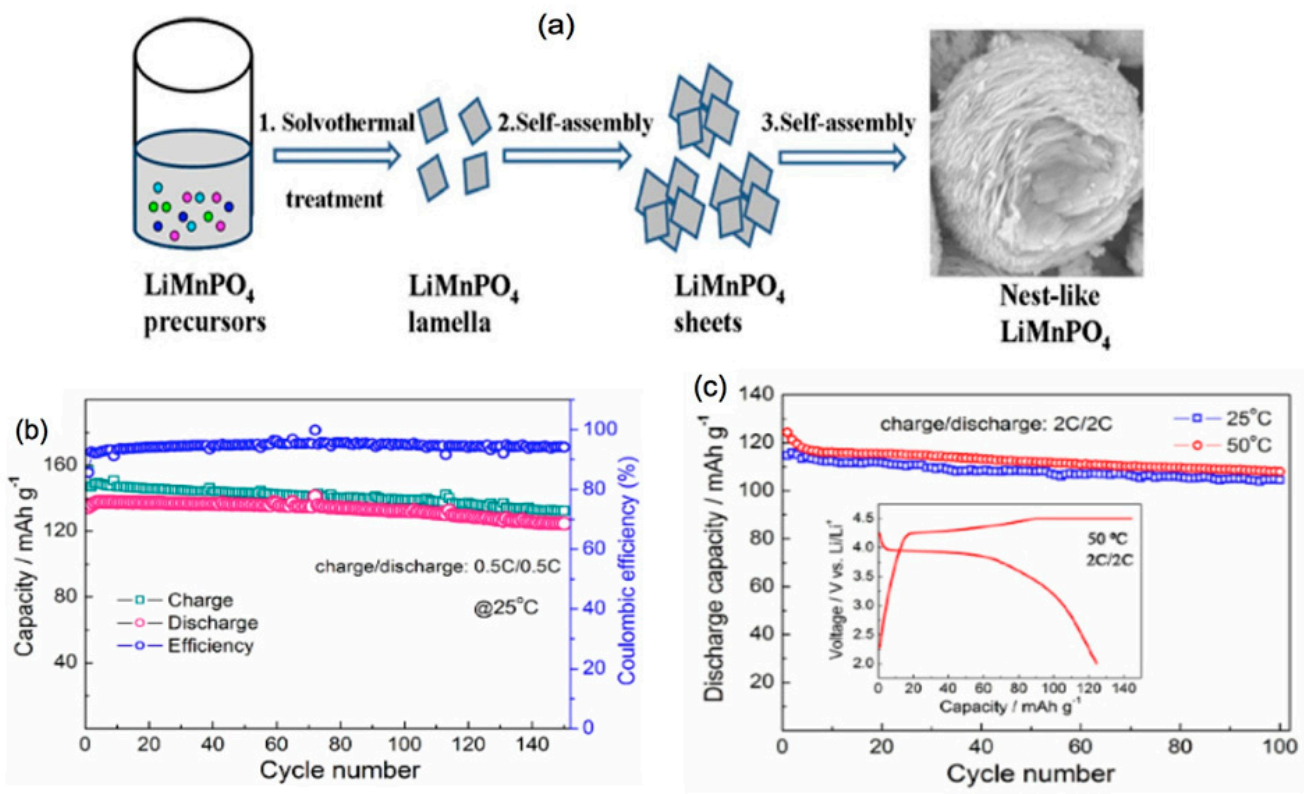

Figure 5. (a) Schematic illustration of the formation process of the porous, nest-like $\mathrm{LiMnPO}_{4}$ microstructures self-assembled with nanosheets in thickness of ca. $30 \mathrm{~nm}$ synthesized by a solvothermal approach. (b,c) show the cycling performances of EC-LMP/C at 25 and $50{ }^{\circ} \mathrm{C}$, respectively. The inset shows the charge/discharge curve at a $2 \mathrm{C}$ rate. Reproduced from [145].

\subsection{Substitution and Doping}

$\mathrm{LiMn}_{1-x} \mathrm{Fe}_{x} \mathrm{PO}_{4}$ (LMFP) exists in all proportions $0 \leq x \leq 1$ and should be considered as a solid solution. Its extensive study is the subject of a subsequent separate section. In the present case, we consider only the substitution of Mn in LMP for other alien ions in the concentration of few atom $\%$, which is the typical order of magnitude used for doping semiconductors and insulators in solid-state science.

Many attempts have been made to increase the performance of LMP by a partial substitution of $\mathrm{Mn}^{2+}$ with other metal ions to improve the conductivity. This is difficult in olivine materials because these materials are ionic in nature and such a substitution costs a high Coulomb energy. Therefore, the limit of solubility of such alien cations will be very small, or will substitute on the Li-site, in which case they will block the Li-channels and degrade the electrochemical properties instead of improving them. Different divalent cations have been explored in the previous decade: $\mathrm{Mg}^{2+}, \mathrm{Co}^{2+}, \mathrm{Ni}^{2+}, \mathrm{Zn}^{2+}$, $\mathrm{Cu}^{2+}$, and $\mathrm{Ca}^{2+}$. The results reviewed elsewhere [1] showed an improvement, but only moderate. The best result is obtained with $\mathrm{Zn}$ [148] provided that the amount of $\mathrm{Zn}$ remains as small as 2 atom \%, in which case a discharge capacity of $139 \mathrm{mAh} \mathrm{g}^{-1}$ was observed at $0.1 \mathrm{C}$, and $105 \mathrm{mAh} \mathrm{g}^{-1}$ at $2 \mathrm{C}$ for a particle size of $200 \mathrm{~nm}$. Unfortunately, the cycling behavior has been tested on 30 cycles only. Raising the Zn concentration to 5 atom \% still improves the electrochemical properties with respect to pure LMP [149], but increasing the concentration to 10 atom \% leads to very poor results, because part of $\mathrm{Zn}$ substitutes for $\mathrm{Li}$ and blocks the lithium channels. A similar effect is observed with $\mathrm{Mg}$ substitution with an optimum $\mathrm{Mg}$ concentration of 5 at $\%$, and a larger concentration leading to a sharp degradation of the electrochemical properties [150]. In the case of $\mathrm{Cu}$, the optimum $\mathrm{Cu}$ concentration is even smaller, namely $2 \%$ [151].

Ce-doping has been proposed [152]. However, the cerium atom is very big and difficult to put in substitution for $\mathrm{Mn}$ in the lattice. On the other hand, it combines easily with $\mathrm{PO}_{4}{ }^{3-}$ to form cerium orthophosphate $\mathrm{CePO}_{4}$. The presence of this impurity is thus likely, and indeed the X-ray photoelectron 
spectroscopy (XPS) results suggest that the cerium is trivalent in the Ce-LMP sample investigated. $\mathrm{CePO}_{4}$ is a semiconductor with direct bandgap of $1.07 \mathrm{~V}$ [153], much smaller than that of $\mathrm{LiMnPO}_{4}$ $(4 \mathrm{eV})$. In addition, part of the cerium can also precipitate, and it is metallic.

The case of doping with a trivalent ion is more promising for improving the conductivity. $\mathrm{Cr}^{3+}$-doping of LMP has been reported [154], following the results reported for Cr-doped LFP. The optimum Cr concentration in Cr-LMP is 6 atom \%. Good electrochemical properties have been reported, but with a cathode containing as much as $20 \%$ Super P Carbon black. To our knowledge, no electrochemical property with Cr-doped LMP has been reported with half the amount of carbon; twice smaller would allow a useful comparison with other LMP-based cathodes and a discussion on the commercial use.

The case of vanadium is interesting. The study of the magnetization properties shows that V-doping leads to the onset of magnetic irreversibility and increased magnetic susceptibility at low magnetic field, with reduction of the irreversibility at high field $[155,156]$. The authors attributed these effects to the movement of domain walls, which, however, is very unlikely. Actually, these properties are characteristics of a spin-glass behavior due to the freezing of diluted spins in a semiconductor (or insulator) matrix and should be analyzed in this context [157]. The consequence is that the magnetic moment of the vanadium ion cannot be deduced from the hysteresis, contrary to the claim in Ref. [156]. Extended X-ray Absorption Fine Structure (EXAFS)/X-ray Absorption Near Edge Structure (XANES) measurements reveal the presence of $\mathrm{V}^{5+}$ [158], but this could be due to the presence of $\mathrm{V}_{2} \mathrm{O}_{5}$ impurities, especially as the concentration of vanadium was high $(10-20 \%)$ while the solubility limit of vanadium in the host has not been investigated. Actually, the assumption that the vanadium is in substitution on the phosphorous site might have been influenced by a former hypothesis suggesting this substitution in V-doped $\mathrm{LiFePO}_{4}$ [159], which was ruled out later on. It is now established that the vanadium in $\mathrm{V}-\mathrm{LiFePO}_{4}$ is in the trivalent state and in substitution for iron, and these results holds true also in the case of the olivine with manganese, as we shall see in the section on $\mathrm{LiMn}_{1-x} \mathrm{Fe}_{x} \mathrm{PO}_{4}$. The highest discharge capacity in V-LMP has been obtained with C-LiMn $\mathrm{L}_{0.075} \mathrm{~V}_{0.025} \mathrm{PO}_{4} / \mathrm{C}$ particles, namely, $108 \mathrm{mAh} \mathrm{g}^{-1}$ at $0.2 \mathrm{C}$ for the first cycle [160]. However, owing to an overpotential already large at this C-rate, the plateau at $4.1 \mathrm{~V}$ was short, so that the discharge capacity in the high-voltage part above $4 \mathrm{~V}$ did not exceed $40 \mathrm{mAh} \mathrm{g}^{-1}$. The consequence is a smaller energy density. The best way to overcome this problem is to form a composite of LMP with graphene.

\subsection{Graphene-LMP Composites}

The addition of graphene or reduced graphene oxide has two beneficial effects. First, it is a good electrical conductor, which increases the rate capability. Second, its very good mechanical properties help in accommodating the volume changes of the active particles during cycling, thus improving the cycle life. This is true for any cathode of Li-ion batteries [161], and this has been testified to in the particular case of LMP in different works [162,163]. Superior results were observed with 300-500 nm thick LMP particles wrapped in $3 \mathrm{wt} \%$ reduced graphene oxide (RGO) [164]. Used as a cathode, this composite delivered a capacity of $160 \mathrm{mAh} \mathrm{g}^{-1}$ at $0.05 \mathrm{C}$. The discharge capacity in the area above 4.0 $\mathrm{V}$ was $115 \mathrm{mAh} \mathrm{g}^{-1}$ owing to the well-known plateau at the redox potential $4.1 \mathrm{~V}$ of the $\mathrm{Mn}^{3+} / \mathrm{Mn}^{2+}$ versus $\mathrm{Li}^{+} / \mathrm{Li}$, so that the cell can take benefit of this high voltage to increase the energy density. Moreover, the capacity at $1 \mathrm{C}$ was still $100 \mathrm{mAh} \mathrm{g}^{-1}$ and after 1000 cycles, the capacity retention was $83 \%$. This remarkable cycle life might be due to the fact that the $\mathrm{Mn}^{2+}$ ions can be adsorbed on the surface of the RGO owing to the oxygen functional groups, preventing $\mathrm{Mn}^{2+}$ from dissolution.

\section{4. $\mathrm{LiMn}_{1-x} \mathrm{Fe}_{x} \mathrm{PO}_{4}$}

Since the higher resistivity of $\mathrm{LiMnPO}_{4}$ prevented the commercialization of this material while $\mathrm{LiFePO}_{4}$ has met major success, the solid solution $\mathrm{LiMn}_{1-x} \mathrm{Fe}_{x} \mathrm{PO}_{4}$ (LMFP) has been investigated to take advantage of both the increase of conductivity brought by $\mathrm{Fe}$, and the higher energy density brought by Mn. This attempt was successful, in particular when the concentration of Mn does not 
exceed 0.8 [165]. Indeed, nano-sized carbon-coated $\mathrm{LiMn}_{1-x} \mathrm{Fe}_{x} \mathrm{PO}_{4}$ particles have shown improved properties [166-177].

However, as already mentioned in the previous section devoted to LMP, using nanoparticles has disadvantages in terms of handing, manufacturing, and volumetric density. To avoid them, hierarchical structures have been synthesized, such as $\mathrm{LiMn}_{0.5} \mathrm{Fe}_{0.5} \mathrm{PO}_{4}$ spheres [178]. Microspheres made of carbon-coated nanocrystalline $\mathrm{LiFe}_{0.6} \mathrm{Mn}_{0.4} \mathrm{PO}_{4}(\sim 100 \mathrm{~nm})$ [179] were synthesized by sintering spherical precursor powders prepared by a modified spray drying method with a double carbon coating process. This product delivered a capacity of $160 \mathrm{mAh} \mathrm{g}^{-1}$ at $0.1 \mathrm{C}$, and a volumetric energy density of $800 \mathrm{Wh} \mathrm{L}^{-1}$-nearly 1.4 times that of their nano-sized counterparts, owing to the high tap density of $1.4 \mathrm{~g} \mathrm{~cm}^{-3}$. In addition, the rate capability was very good since the capacity retained at $5 \mathrm{C}$ was $128 \mathrm{mAh} \mathrm{g}^{-1}$ and the energy density was $420 \mathrm{Wh} \mathrm{L}^{-1}$. Even at $20 \mathrm{C}$, the capacity was still $106 \mathrm{mAh} \mathrm{g}^{-1}$, very stable over 300 cycles. This superior electrochemical performance validates the strategy aiming to obtain a product made of particles with two length scales: micron-size for secondary particles to obtain a high tap density and, thus, large volumetric energy density, and nano-size for the primary particles to obtain a high rate capability. Note that the precursor used for the carbon coating was sucrose, and the cathode slurry was $80 \mathrm{wt} \%$ active material, $10 \mathrm{wt} \% \mathrm{PVdF}$, and only $10 \mathrm{wt} \%$ carbon black. These results are also improvements with respect to other attempts to increase the tap density through the synthesis of micro-sized materials [128,180-182] because the intrinsic conductivity of the olivine is so small that the inner part of micro-sized particles cannot participate in the electrochemical process. The combination of nano-sized crystallites forming micron-sized secondary particles is the best configuration when the electrolyte can penetrate the secondary particles.

\subsection{Carbon Coating}

Recently, nano-sized $\mathrm{LiFe}_{0.6} \mathrm{Mn}_{0.4} \mathrm{PO}_{4} / \mathrm{C}$ has been prepared by a high-energy ball-milling-assisted sol-gel method, with a much more conductive carbon coating than in prior works [183]. The Raman spectroscopy revealed a larger intensity of the graphitic " $G$ band" with respect to the " $D$ band" characteristic of the disordered carbon. Specific capacities of 128 and $116 \mathrm{mAh} \mathrm{g}^{-1}$ and capacity retentions of $93.5 \%$ and $90.3 \%$ after 100 cycles at $1 \mathrm{C}$ and 2 C, respectively, were reported. The authors attributed this result to the improved conductivity of the carbon coating. However, a ferromagnetic component of the magnetization curve implies the presence of $\mathrm{Fe}_{2} \mathrm{P}$ impurities. Since $\mathrm{Fe}_{2} \mathrm{P}$ is metallic, it also improves the rate capability. The authors also prepared LMP/C using the same process (high-energy ball-milling-assisted sol-gel) to make a comparison and found that the electrochemical properties of the $\mathrm{LiFe}_{0.6} \mathrm{Mn}_{0.4} \mathrm{PO}_{4} / \mathrm{C}$ were superior to those of $\mathrm{LMP} / \mathrm{C}$, as expected. However, $\mathrm{LMP} / \mathrm{C}$ is free of $\mathrm{Fe}_{2} \mathrm{P}$ impurities, so part of this difference might actually be attributed to this impurity brought by iron. Nevertheless, part of this difference is also attributable to the beneficial effect of the increase of the $\mathrm{Li}^{+}$diffusion brought by $\mathrm{Fe}$, and also the better electrical conductivity of the carbon coating owing to the $\mathrm{Fe}-\mathrm{C}$ interaction. On another hand, this result also shows that even the best carbon coating cannot replace the wrapping of the particles by graphene, since the performance of LMP wrapped in RGO is still better [164].

A remarkable result was obtained owing to a chemical vapor deposition (CVD) approach to coat $\mathrm{LiMn}_{0.8} \mathrm{Fe}_{0.2} \mathrm{PO}_{4}$ agglomerated primary particles (40-50 nm in diameter) with a higher degree of graphitization [184]. The capacity reached $151 \mathrm{mAh} \mathrm{g}^{-1}$ at $0.1 \mathrm{C}$ with a capacity retention of $96 \%$ after 450 cycles. The capacity at $5 \mathrm{C}$ was still $133 \mathrm{mAh} \mathrm{g}{ }^{-1} \cdot \mathrm{LiMn}_{0.5} \mathrm{Fe}_{0.5} \mathrm{PO}_{4} / \mathrm{C}$ synthesized by a surfactant-assisted solid-state method exhibited specific capacities of 155, 141, and $121 \mathrm{mAh} \mathrm{g}^{-1}$ at $0.1 \mathrm{C}, 1 \mathrm{C}$, and $5 \mathrm{C}$, respectively, with capacity retention of $94.8 \%$ and $90.8 \%$ after 500 cycles at $1 \mathrm{C}$ and 5 C, respectively [185]. In terms of capacities, the results obtained in these two references are comparable. However, the larger concentration of Mn in Ref. [184] gives an advantage to the CVD approach in terms of energy density, owing to the higher redox potential of manganese.

As an alternative to graphene, multiwalled carbon nanotube (MWCNT)-loaded mesoporous $\mathrm{LiFe}_{0.6} \mathrm{Mn}_{0.4} \mathrm{PO}_{4} / \mathrm{C}$ microspheres were synthesized. The composite with $2 \mathrm{wt} \% \mathrm{MWCNT}$ loading 
delivered $163,154,149,137,131,120$, and $114 \mathrm{mAh} \mathrm{g}^{-1}$ at $0.1 \mathrm{C}, 0.5 \mathrm{C}, 1 \mathrm{C}, 3 \mathrm{C}, 5 \mathrm{C}, 10 \mathrm{C}$, and $20 \mathrm{C}$, respectively, with no apparent capacity fading over 500 cycles [186]. This is a remarkable result that can be attributed to the synergetic effect of (i) the hierarchical structure: spherical secondary particles $(5-20 \mu \mathrm{m})$ made of primary particles (100 nm); (ii) open mesopores; and (iii) highly conductive MWCNTs. However, the growth of carbon nanotubes is slow and expensive, so it is difficult to use them in an industrial process.

\subsection{Doping}

Partial substitution of the transition metal ions in $\mathrm{LiMn}_{1-x} \mathrm{Fe}_{x} \mathrm{PO}_{4}$ was also explored and is usually referred to in the literature as co-doping of LMP or LFP. The term "doping" is in principal being misused in the battery community, as in almost all cases substitution is being carried out. The results are usually an improvement with respect to single doping. Such is the case, in particular, for co-doping $\mathrm{Fe}^{2+}$ and $\mathrm{Mg}^{2+}$ of LMP [187-198], co-doping Fe and Co [199], and co-doping Fe and Ti [200]. In the latter case, $\mathrm{Li}\left(\mathrm{Mn}_{0.85} \mathrm{Fe}_{0.15}\right)_{0.92} \mathrm{Ti}_{0.08} \mathrm{PO}_{4} / \mathrm{C}$ delivered a capacity of $144 \mathrm{mAh} \mathrm{g}^{-1}$ with a capacity retention close to $100 \%$ over 50 cycles at $1 \mathrm{C}$. Note, however, that a systematic approach for a multi-element doping design in electrode materials for rechargeable batteries by an elitism-improved nondominated sorting genetic algorithm (NSGA-II) optimization led to the conclusion that the best electrochemical performance is expected for multi-doping LMP with optimum compositions $\mathrm{LiMn}_{0.938} \mathrm{Mg}_{0.024} \mathrm{Co}_{0.016} \mathrm{Ni}_{0.022} \mathrm{PO}_{4} / \mathrm{C}$ and $\mathrm{LiMn}_{0.962} \mathrm{Co}_{0.012} \mathrm{Ni}_{0.026} \mathrm{PO}_{4} / \mathrm{C}$ [201]. In both cases, the capacity delivered was $150 \mathrm{mAh} \mathrm{g}^{-1}$ at low C-rate and $110 \mathrm{mAh} \mathrm{g}^{-1}$ at $2 \mathrm{C}$ rates with $91 \%$ capacity retention during 30 cycles. In terms of capacity and rate capability, these two samples do not outperform co-doped LMP in which Fe is one of the dopants.

The investigation of $\mathrm{V}$-doping has been made recently in $\mathrm{LiMn}_{0.8} \mathrm{Fe}_{0.2} \mathrm{O}_{4}$ [86] with $3 \% \mathrm{~V}$-insertion, a small concentration to make sure that it is below the threshold of solubility; otherwise, $\mathrm{Li}_{3} \mathrm{~V}_{2}\left(\mathrm{PO}_{4}\right)_{3}$ impurities are formed [202]. V substitutes for $\mathrm{Fe}$, and this substitution is accompanied by the formation of Fe vacancies like in V-LFP, leading to a composition of $\mathrm{LiMn}_{0.8} \mathrm{Fe}_{0.2-0.045} \mathrm{~V}_{0.03} \square_{0.015} \mathrm{PO}_{4}$, where $\square$ is a Fe vacancy. Before cycling, the cell is at open circuit voltage $(2.6 \mathrm{~V})$, in which case the vanadium is in the trivalent $\mathrm{V}^{3+}$ state, while $\mathrm{Mn}$ remains in the $\mathrm{Mn}^{2+}$ valence state. On another hand, during cycling, a reversible $\mathrm{V}^{3+} / \mathrm{V}^{2+}$ is observed when the potential of the half-cell is lowered below the redox potential of $1.8 \mathrm{~V}$ versus $\mathrm{Li}^{+} / \mathrm{Li}$, owing to the insertion of $\mathrm{Li}$ on the $\mathrm{Li}$ vacancies that are present before cycling. Therefore, when cycling in the full potential range $0-4.5 \mathrm{~V}$, all the transition metal ions $\mathrm{Fe}, \mathrm{Mn}$, and $\mathrm{V}$ are active and change their valence between $2+$ and $3+$, in which case the theoretical capacity remains unchanged. On another hand, the insertion of $\mathrm{V}$ increases the diffusion coefficient of the $\mathrm{Li}^{+}$ions (see Figure 6) and thus facilitates the extraction of lithium, resulting in an increase of the experimental capacity, in particular at high C-rate. The diffusion coefficient of lithium has long been investigated in $\mathrm{LiFePO}_{4}$ and $\mathrm{LiMnPO}_{4}$ and more recently in the solid solution $\mathrm{LiMn}_{1-x} \mathrm{Fe}_{x} \mathrm{PO}_{4}$ [203]. The results, however, were difficult to interpret because of the large differences found between the determination of this coefficient by different techniques: galvanostatic acceleration (PCGA), cyclic voltammetry (CV), electrochemical impedance spectroscopy (EIS), and the galvanostatic intermittent titration technique (GITT). However, in Ref. [86], GITT and EIS analyses gave the same value of the diffusion coefficient (see Figure 6) and demonstrated that the insertion of vanadium increases the electrical conductivity and the ionic conductivity at any state of charge of the cathode material. This is the reason why the insertion of vanadium is beneficial to the rate capability and reduces the polarization of the cell. 

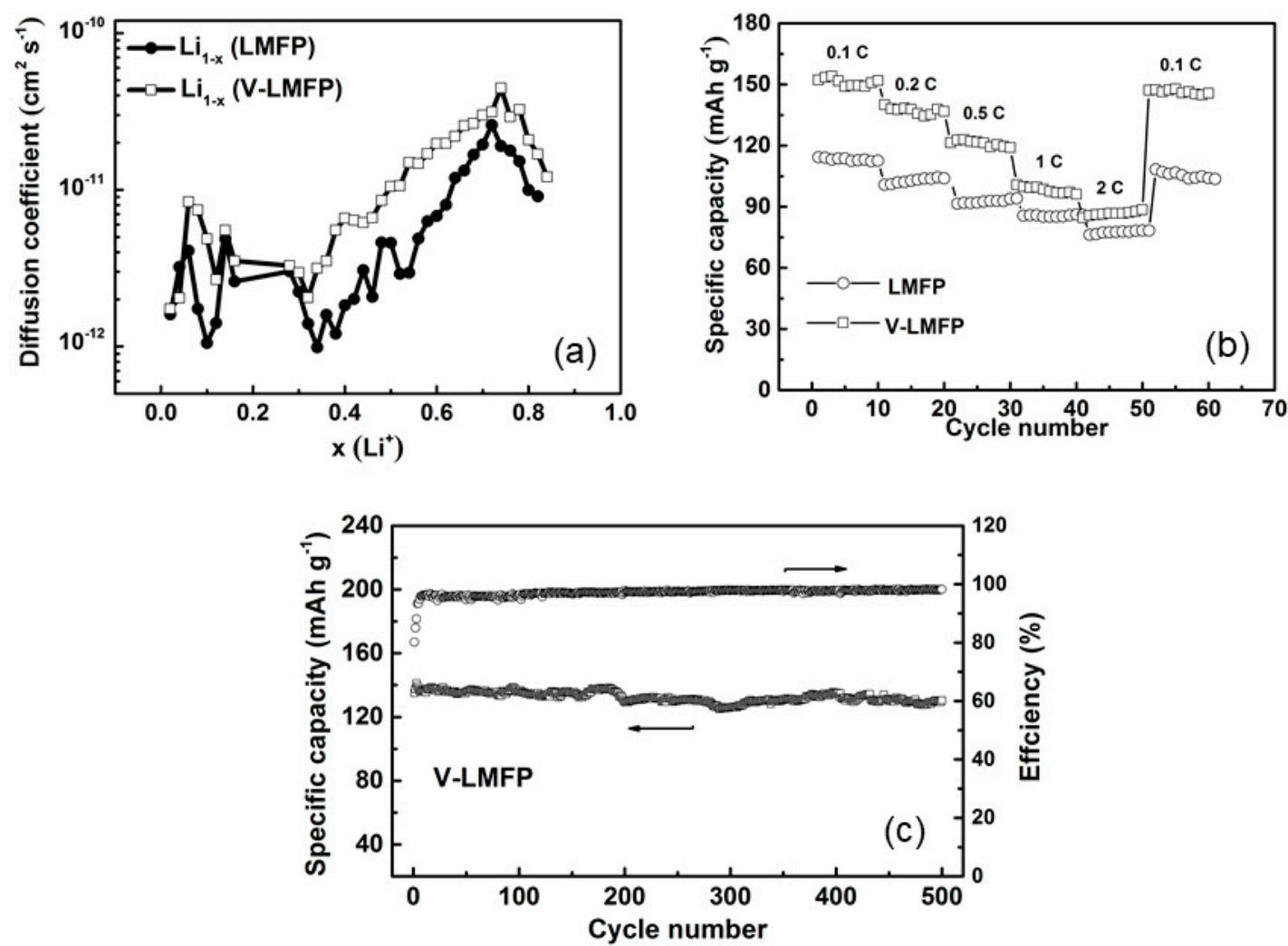

Figure 6. (a) Apparent diffusion coefficient of $\mathrm{Li}^{+}$ion determined from galvanostatic intermittent titration technique (GITT) measurements for $\mathrm{LiMn}_{0.8} \mathrm{Fe}_{0.2} \mathrm{PO}_{4}$ (LMFP, circles) and $\mathrm{LiMn}_{0.8} \mathrm{Fe}_{0.2-0.045} \mathrm{~V}_{0.03} \square_{0.015} \mathrm{PO}_{4}$ (V-LMFP, squares). Triangles are data obtained from electrochemical impedance spectroscopy (EIS) experiments for V-LMFP. (b) Rate capability. (c) Cyclability of the $\mathrm{Li} / / \mathrm{V}-\mathrm{LMFP}$ cell charged and discharged at $0.2 \mathrm{C}$ rate. Reproduced from [86].

\subsection{Core-Shell Composites}

Since the carbon coating of LMP is more difficult than that of LFP, an LMP-LFP composite has been synthesized in which the carbon-coated LFP encapsulates the LMP core region. The particles thus obtained were well-crystallized grains several tens to $100 \mathrm{~nm}$ in size [204]. Elemental analysis indicated the LMP-LFP (66:33) composition and a comparison of the electrochemical properties has been made with those of the solid solution $\mathrm{LiMn}_{0.66} \mathrm{Fe}_{0.33} \mathrm{PO}_{4}$ which has the same $\mathrm{Mn} / \mathrm{Fe}$ ratio and same grain size. As a result, the properties of the core-shell structure are better, with an initial capacity of $144 \mathrm{mAh} \mathrm{g}^{-1}$-nearly twice the capacity delivered by the solid solution. At $1 \mathrm{C}$ rate, the blend retained $65 \mathrm{mAh} \mathrm{g}^{-1}$ against $23 \mathrm{mAh} \mathrm{g}^{-1}$ for the solid solution. The authors attributed this result to the synergetic effect of the improved carbon coating owing to the LFP shell, and a protection of the LMP part by the LFP shell against side reactions with the electrolyte. The same experiments on LMP-LFP (80:20) and $\mathrm{LiMn}_{0.80} \mathrm{Fe}_{0.20} \mathrm{PO}_{4}$ have confirmed the superior behavior of the core-shell structure over the solid solution [205] (see Figure 7). In this case, the performance of the core-shell structure was remarkable, because the different synthesis process, a dimethyl sulfoxide (DMSO)-assisted aqueous method, allowed the formation of much smaller particles, which were coral-shape particles with the longest dimension approximately $100 \mathrm{~nm}$. The core-shell samples exhibited capacities of 156,144 , and $128 \mathrm{mAh} \mathrm{g}^{-1}$ at $0.1 \mathrm{C}, 1 \mathrm{C}$, and $5 \mathrm{C}$, respectively, retaining $95 \%$ of the initial capacities after 1000 cycles under $1 \mathrm{C}$ discharging rate. The authors deduced from these results that the main reason for the poor electrochemical activity of $\mathrm{LiMnPO}_{4}$ is related to the surface polarization. Surface effects were confirmed by density functional calculations, showing a decrease 
of the barrier for Li to diffuse in LMP in the vicinity of the LMP-LFP interface, which increases the diffusion coefficient by orders of magnitude with respect to the diffusion of pure LMP [206].

Core-shell structures with good ionic conductors such as $\mathrm{LiMnPO}_{4} @ \mathrm{Li}_{2} \mathrm{TiO}_{3} / \mathrm{C}$ [144] or $\mathrm{LiMnPO}_{4} @ \mathrm{~V}_{2} \mathrm{O}_{5} / \mathrm{C}$ have also been synthesized and have good electrochemical properties [207]. LiMnPO ${ }_{4} @ \mathrm{Li}_{3} \mathrm{~V}_{2}\left(\mathrm{PO}_{4}\right)_{3}$ has also been synthesized [208], but the electrochemical properties do not reach those of the LMP-LFP (80:20) material in Ref. [205].

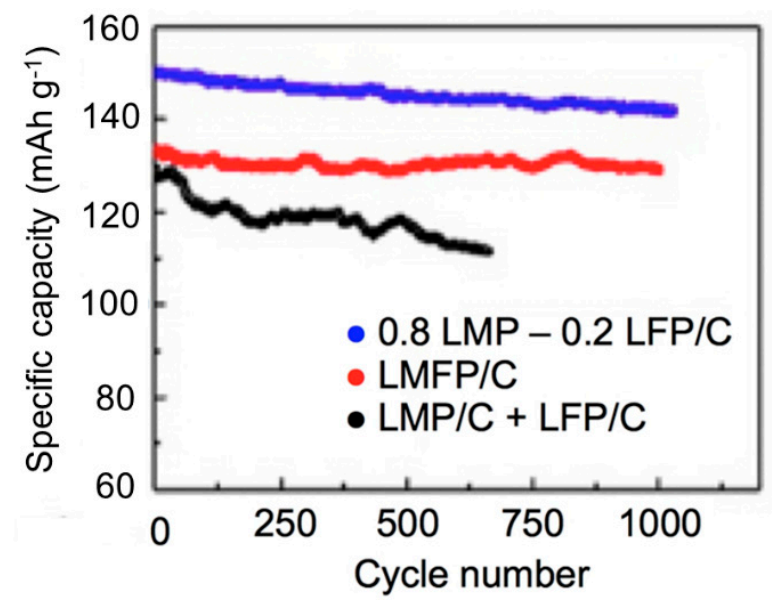

Figure 7. Cycling performances at a discharge rate of $1 \mathrm{C}$ for the core-shell structure $0.8 \mathrm{LMP}-0.2 \mathrm{LFP} / \mathrm{C}$, the solid solution with the same $\mathrm{Mn} / \mathrm{Fe}$ molar ratio $\mathrm{LiMn}_{0.8} \mathrm{Fe}_{0.2} \mathrm{PO}_{4}(\mathrm{LMFP} / \mathrm{C})$, and the simple mixture LMP/C + LFP/C. Reproduced from [205].

\section{5. $\mathrm{LiCoPO}_{4}$}

The advantage of $\mathrm{LiCOPO}_{4}(\mathrm{LCP})$ lies in its high working potential of $4.8 \mathrm{~V}$ versus $\mathrm{Li}^{+} / \mathrm{Li}$, which is higher than that of $\mathrm{Li}(\mathrm{Fe}, \mathrm{Mn}) \mathrm{PO}_{4}$ but still in the electrochemical window. Therefore, even though its theoretical capacity of $167 \mathrm{mAh} \mathrm{g}^{-1}$ is nearly the same as that of $\mathrm{LiFePO}_{4}$, its theoretical gravimetric energy density is higher at $800 \mathrm{Wh} \mathrm{kg}^{-1}$; note, however, that the volumetric energy density is smaller at $510 \mathrm{Ah} \mathrm{L}^{-1}$ (see Table 1 and Figure 1 for comparison). The voltage capacity curve is different from that of the $\mathrm{LiFePO}_{4}$ and $\mathrm{LiMnPO}_{4}$ since it does not reduce to a single plateau. The reason for this is the existence of $\mathrm{Li}_{2 / 3} \mathrm{CoPO}_{4}$ stable with respect to the disproportionation, leading to the formation of $\mathrm{LiCoPO}_{4}$ and $\mathrm{CoPO}_{4}$ [209]. On another hand, cobalt is expensive, toxic, and the conditions of extraction are repeatedly criticized by Amnesty International. For both ethics considerations and protection of the environment, efforts should then be made to avoid the use of cobalt. From a strictly scientific perspective, however, the material is promising, and we have recently pointed to the constant progress in its electrochemical performance [210]. The common feature to the olivine family is low intrinsic conductivity, a problem that should be solved as usual by surface modification. With respect to $\mathrm{LiFePO}_{4}$, however, two additional problems are met with $\mathrm{LiCoPO}_{4}$ : structural deterioration upon cycling, and electrolyte decomposition [211].

Like in the case of the other olivine compounds, the problem of low conductivity can be solved by decreasing the size of the particles [212-215] and optimizing the carbon coating [216-219]. The presence of carbon in the grinding media is not sufficient [220]. $\mathrm{LiCoPO}_{4}$ free of any impurity can be obtained even if the sintering temperature used for the carbon coating is raised to $750{ }^{\circ} \mathrm{C}$ [221], a temperature high enough to make the carbon layer conductive. A capacity of $130 \mathrm{mAh} \mathrm{g}^{-1}$ stable over 50 cycles was obtained with a carbon coating that was thick $(8 \mathrm{~nm})$ but inhomogeneous. Actually, the homogeneity of the carbon coating is not important, provided that the covering of the particles is large so that the carbon structure percolates through the powder to conduct the electrons to the current collector. According to recent investigations, this condition is fulfilled when the amount of carbon involved in the carbon coating reaches $0.8 \mathrm{wt} \%$ [222]. 
As an alternative to carbon coating, uniform $4 \mathrm{~mol} \% \mathrm{AlF}_{3}$-modified $\mathrm{LiCoPO}_{4}$ was synthesized. The material delivered a capacity of $159 \mathrm{mAh} \mathrm{g}^{-1}$ at $0.1 \mathrm{C}$ with $91 \%$ capacity retention after 50 cycles, and a discharge capacity of $90 \mathrm{mAh} \mathrm{g}^{-1}$ was obtained at $1 \mathrm{C}$ [223]. $\mathrm{Li}_{3} \mathrm{PO}_{4}$-modified $\mathrm{LiCoPO}_{4}$ delivered $164 \mathrm{mAh} \mathrm{g}^{-1}\left(787 \mathrm{Wh} \mathrm{kg}^{-1}\right.$ ) at $0.1 \mathrm{C}$ and $117 \mathrm{mAh} \mathrm{g}^{-1}\left(561 \mathrm{Wh} \mathrm{kg}^{-1}\right)$ at a $5 \mathrm{C}$ rate [224]. $\mathrm{A} \mathrm{LiFePO}_{4}$ shell was also used to improve the storage properties and cyclability $[225,226]$. Attention should be paid, however, to the fact that the thermal stability of LCP at $5 \mathrm{~V}$ is similar to that of lamellar compounds (while it is much better at the operational voltage $3.5 \mathrm{~V}$ of LFP).

The first doping approach has been the partial substitution of Co by Fe [227-231] and Mn [232], which amounts to mixing $\mathrm{LiCoPO}_{4}$ with the other members of the olivine family to obtain solid solutions. We can expect from Fe and Mn substitution an increase of the stability of the lattice and less side effects with the electrolyte, and, therefore, an increase in the cycle life. However, in addition, the operational voltages of $\mathrm{LiFePO}_{4}$ and $\mathrm{LiMnPO}_{4}$ at $3.45 \mathrm{~V}$ and $4.1 \mathrm{~V}$, respectively, imply that Fe and $\mathrm{Mn}$ are in the trivalent state in the voltage range where cobalt is active. Therefore, in the potential range 3.5-4.8 $\mathrm{V}, \mathrm{Fe}^{3+}$ substitutes for $\mathrm{Co}^{2+}$, the charge compensation being ensured by $\mathrm{Li}$ vacancies, so that iron plays the role of an aliovalent ion and we can expect an increase of conductivity. The same is true for Mn substitution, but only above 4.1 V. Mn substitution improved the electrochemical properties, but not much. Fe substitution was more successful, in particular after annealing at $700{ }^{\circ} \mathrm{C}$ under argon atmosphere. The combination of Fe-doping and annealing reduces the concentration of antisite defects, and also leads to an expansion of the diffusion channels along the (010) direction in the vicinity of iron ions $[227,231]$. The first effect enhances the capacity and the second effect results in an increase of the lithium diffusion, also observed in Ref. [233], which contributes to enhancing the rate capability. These effects specific to Fe-doping presumably explain the success of Fe-doping with respect to Mn-doping.

Substitution of Co for isovalent ions such as $\mathrm{Mg}[234,235]$ and $\mathrm{Ca}[234,236]$ was not as successful as the substitution of $\mathrm{Co}$ for Fe. The only sizeable effect was a decrease in the charge transfer resistance, which may be due to the stabilization of the delithiated phase during cycling.

A more significant improvement with respect to $\mathrm{Mg}$ - and $\mathrm{Ca}$-doping is expected from doping with an aliovalent ion, since in that case one can expect not only a stabilization of the lattice by the substitution for $\mathrm{Co}$, but also an increase in the electrical and ionic conductivity owing to the different charge on the cation site that should favor Li vacancies and the polaronic conductivity of the holes. In this context, V-doping was investigated and had the same positive effect on the electrochemical properties as in LFP and LMP, since the vanadium substitutes for the transition metal in the trivalent state in the voltage range of interest [237]. Then the synergetic effects of V-doping and coating with $\mathrm{LiFePO}_{4}$ were investigated by Kreder and Manthiram [225] on $\mathrm{LiCo}_{1-3 x / 2} \mathrm{~V}_{x} \square_{x / 2} \mathrm{PO}_{4}(x=0,0.02$ and 0.04$)$ with $5 \mathrm{wt} \%$ LFP. As a result, the specific capacity at $0.1 \mathrm{C}$ was raised to $145 \mathrm{mAh} \mathrm{g}^{-1}$ at $0.1 \mathrm{C}$ rate, but the capacity fade was still important, as the capacity fell to circa $80 \mathrm{mAh} \mathrm{g}^{-1}$ after 20 cycles. $\mathrm{Y}^{3+}$-doping effects were investigated in Ref. [238]. The initial discharge capacity was raised to $154 \mathrm{mAh} \mathrm{g}^{-1}$. However, the capacity retention was not improved ( $21 \%$ after 30 cycles). $\mathrm{Cr}^{3+}$-doping increases the electrical conductivity from $10^{-9}$ to $10^{-4}$ $\mathrm{S} \mathrm{cm}^{-1}$ [239]. In addition, $\mathrm{Cr}$ substitution, like Fe substitution [233], reduces the concentration of antisite defects. As a result, $\mathrm{LiCo}_{1-1.5 x} \mathrm{Cr}_{x} \mathrm{PO}_{4} / \mathrm{C}(x=0.04)$ delivered a capacity of $144 \mathrm{mAh} \mathrm{g}^{-1}$ at $0.1 \mathrm{C}$ with a capacity retention of $71 \%$ after 100 cycles [240]. This cyclability is much better than the results obtained with the other dopants we have mentioned. Silicon is also a dopant, as it can substitute to the transition metal ion in the $\mathrm{Si}^{4+}$ valence state, with $\mathrm{Li}$ vacancies ensuring charge compensation [241]. An outstanding result was then obtained by the synergetic effect of $\mathrm{Cr}$ plus Fe-doping plus Si-doping by Allen et al. [228] who synthesized $\mathrm{Cr}$, Si-LiCo ${ }_{0.9} \mathrm{Fe}_{0.1} \mathrm{PO}_{4}$. The actual composition reported in this work was $\mathrm{LiCo}_{0.82} \mathrm{Fe}_{0.0976} \mathrm{Cr}_{0.0488} \mathrm{Si}_{0.00976} \mathrm{PO}_{4}$, but the structural model deduced from the refinement of neutron and synchrotron diffraction data gave the result $\left(\mathrm{Li}_{0.930} \mathrm{Cr}_{0.005} \mathrm{Fe}_{0.001}\right)_{\mathrm{M} 1}\left(\mathrm{Co}_{0.822} \mathrm{Fe}_{0.107} \mathrm{Cr}_{0.056} \mathrm{Si}_{0.012} \mathrm{Li}_{0.015}\right)_{\mathrm{M} 2} \mathrm{PO}_{4}$, which is not exactly the same, and probably more realistic since this last formula gives evidence of $\mathrm{Li}$ vacancies on the $\mathrm{M} 1$ site, and the 
existence of a residual concentration of antisite defects. Note, however, that the occupancy of the M2 site according to this formula is larger than 1 (it is 1.012) which is unphysical and implies that experimental error relates not only to the fourth, but also to the third decimal place. The electrochemical properties were measured in the voltage range $3.0 \mathrm{~V}$ to $4.8 \mathrm{~V}$, so both $\mathrm{Co}$ and $\mathrm{Fe}$ are active. Since the $\mathrm{Co}+\mathrm{Fe}$ concentration was 0.93 , the theoretical capacity is 0.93 times that of $\mathrm{LiCoPO}_{4}$, i.e., $148 \mathrm{mAh} \mathrm{g}^{-1}$. The experimental discharge capacity measured with Li metal as counterelectrode was $\sim 140 \mathrm{mAh} \mathrm{g}^{-1}$ at the $\mathrm{C} / 3$ rate, close to the theoretical value, with $100 \%$ capacity retention over 250 cycles. The discharge capacity remains approximately the same from C/10 to $1 \mathrm{C}$ with only a slight reduction of about $5 \%$ (see Figure 8). The half-cell energy density at the initial cycle and 250th cycle changes only from 665 to $647 \mathrm{Wh} \mathrm{kg}^{-1}$, indicating that in addition to capacity stability the voltage remains stable in the half cell. The full cell (graphite anode) shows some fade due to the loss of cyclable Li owing to the Li-consuming growth of the graphite solid electrolyte interphase (SEI). Still, after 250 cycles the energy supplied is $510 \mathrm{Wh} \mathrm{kg}^{-1}$, so there is an approximately $0.16 \mathrm{Wh} \mathrm{kg}^{-1}$ loss in energy stored per cycle. Note that this performance in both half and full cells was obtained owing to the addition of $2 \mathrm{wt} \%$ conductive carbon nanotubes to $8 \mathrm{wt} \%$ super-P carbon as the carbon additive to prepare the cathode electrode. The same cathode was recently used in a standard CR2032 coin half-cell but was cycled only in the range 3.6-5.0 V so that the iron was not active. The capacity was thus reduced to the contribution of the cobalt only in concentration $0.82\left(125 \mathrm{mAh} \mathrm{g}^{-1}\right.$ at C/3 instead of $\left.140 \mathrm{mAh} \mathrm{g}^{-1}\right)$ [242].

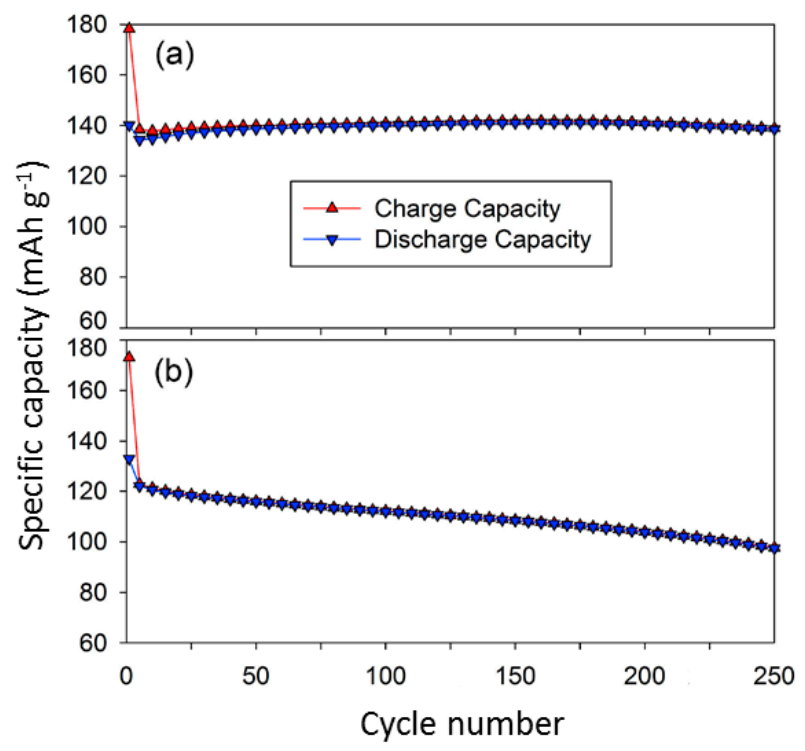

Figure 8. Charge and discharge capacity of $\mathrm{Cr}$, Si-doped $\mathrm{LiCo}_{0.9} \mathrm{Fe}_{0.1} \mathrm{PO}_{4}(\mathbf{a})$ half cells and (b) full cells as a function of cycle number. Reproduced from [228].

\section{6. $\mathrm{LiNiPO}_{4}$}

In a recent review on $\mathrm{LiNiPO}_{4}$ (LNP) [211], we argued why we are pessimistic on its potential applications for different reasons. One argument was that the discharge voltage at $5.1 \mathrm{~V}$ is outside the window of organic liquid electrolytes [243]. Recently, however, Cherkashinin et al. reported that $\mathrm{LiNiPO}_{4}$ films are chemically compatible with $\mathrm{LiPF}_{6} / \mathrm{DMC} / \mathrm{FEC} / 0.2 \%-\mathrm{TMB}$ electrolyte [244]. The $\mathrm{LiNiPO}_{4}$ films grown at high temperatures $\left(\sim 740{ }^{\circ} \mathrm{C}\right)$ form more stable SEI, where no decomposition of the $\mathrm{LiNiPO}_{4}$ surface occurs up to $5.2 \mathrm{~V}$ [244]. The authors concluded that it is a first step towards the design and preparation of stable and redox active olivine- $\mathrm{LiNiPO}_{4}$ thin-film cathode material.

Another argument against $\mathrm{LiNiPO}_{4}$ in Ref. [211] was the difficulty to prepare this material free of defects or impurity. A particular microwave-assisted method was proposed this year by Örnek [245], 
which led to an antisite disorder of $1 \%$ but still a $\mathrm{Ni}_{3} \mathrm{P}$ impurity reflection in the XRD spectra, and the capacity of $58 \mathrm{mAh} \mathrm{g}^{-1}$ at $0.1 \mathrm{C}$ almost vanished after 45 cycles.

The partial substitution of $\mathrm{Co}$ for $\mathrm{Ni}$ increases the capacity but even in most recent works, the capacity retention remains very small [246]. Better results were obtained with $\mathrm{LiNi}_{1-x} \mathrm{Mn}_{x} \mathrm{PO}_{4}$ $(x=0.05-0.2)$ cathode materials prepared by a facile polyol method [247]. In particular, for $x=0.1$, the initial discharge capacity was $94 \mathrm{mAh} \mathrm{g}^{-1}$ at C/4 rate, and $62 \%$ capacity retention after 100 cycles between 2.8 and $5.6 \mathrm{~V}$.

\section{Concluding Remarks}

The results of the intensive research on the olivine family in recent years have been reviewed. Due to the outstanding performance of $\mathrm{LiFePO}_{4}$ for which the experimental discharge capacity is close to the theoretical one, the progress concerns mainly the increase of the electrical conductivity of the carbon coating and the increasing use of graphene and carbon nanotubes. This technology resulted in a remarkable rate capability so that the LFP material can now even be used as an active element in supercapacitors. It should be noted, however, that the growth of carbon nanotubes is slow, which is an obstacle to their commercial use, and some progress is still needed before mass production of graphene can be envisioned.

The progress on $\mathrm{LiMnPO}_{4}$ is remarkable, mainly due to the use of surfactants to obtain uniform and more graphitic carbon coating. Without graphene, with an appropriate surface modification, specific capacities of 132 and $118 \mathrm{mAh} \mathrm{g}^{-1}$ at $0.5 \mathrm{C}$ and $2 \mathrm{C}$, respectively, with a capacity retention of $93 \%$ after 240 cycles at $2 \mathrm{C}$ can now be obtained. With the LMP-LFP core-shell composite, capacities of 156 and $128 \mathrm{mAh} \mathrm{g}^{-1}$ were delivered at $0.1 \mathrm{C}$, and $5 \mathrm{C}$, respectively, and $\sim 95 \%$ of the initial capacity was retained after 1000 cycles under a $1 \mathrm{C}$ discharging rate, outperforming $\mathrm{LiFePO}_{4}$ in term of energy density. On another hand, the cost of this composite cathode will be higher than that of $\mathrm{LiFePO}_{4}$ because the synthesis process requires the coating of the $\mathrm{LiMnPO}_{4}$ core by a $\mathrm{LiFePO}_{4}$ layer in addition to the carbon coating, i.e., an additional step in the process. The success of the LMP-LFP composite at the industrial scale will then depend on the price of the cathode per kWh.

Concerning the $5-\mathrm{V}$ class, the last results confirm our optimism on the increasing performance of $\mathrm{LiCoPO}_{4}$ as a cathode, while we are pessimistic on the future of $\mathrm{LiNiPO}_{4}$. Remarkable results with $\mathrm{Cr}$ and $\mathrm{Si}$ co-doping of $\mathrm{LiCoPO}_{4}$ were obtained provided that the counter-electrode was a Li-metal anode to avoid capacity fading due to the graphite anode in the full cell. The main problem with this material, however, will be the cost. Cobalt is very expensive, $\$ 80$ per $\mathrm{kg}$ on the market, while iron is very cheap. Iron ore fines are approximately $\$ 0.07$ per $\mathrm{kg}$. As a consequence, $\mathrm{LiFePO}_{4}$ can be found at the price of $\$ 45$ per kg, against $\$ 6900$ per kg for $\mathrm{LiCoPO}_{4}$. It is then difficult to imagine that $\mathrm{LiCoPO}_{4}$ can be developed beyond a niche market like satellites since only the energy density matters for such a use, not the price. Finally, we recall that Amnesty International and other organizations denounce the conditions of extraction of cobalt by children in the mines. Obviously, these conditions are also an obstacle to the use of cobalt, but this problem cannot be solved by scientists.

Author Contributions: A.M. wrote the paper. C.M.J. contributed and gave important suggestions about the entire content.

Funding: This research received no external funding.

Conflicts of Interest: The authors declare no conflict of interest.

\section{References}

1. Zaghib, K.; Mauger, A.; Julien, C.M. Olivine-based cathode materials. In Green Energy, Technology: Rechargeable Batteries Materials, Technologies and New Trends; Zhang, Z., Zhang, S.S., Eds.; Springer Science: Hoboken, NJ, USA, 2015; Chapter 3; pp. 25-65.

2. Julien, C.M.; Mauger, A.; Vijh, A.; Zaghib, K. Lithium Batteries: Science and Technology; Springer: Cham, Switzerland, 2016. 
3. Reddy, M.V.; Subba Rao, G.V.; Chowdari, B.V.R. Metal oxides and oxysalts as anode materials for Li ion batteries. Chem. Rev. 2013, 113, 5364-5457. [CrossRef] [PubMed]

4. Mauger, A.; Julien, C.M. Critical review on lithium-ion batteries: Are they safe? Sustainable? Ionics 2017, 23, 1933-1947. [CrossRef]

5. Andre, D.; Kim, S.-J.; Lamp, P.; Lux, S.F.; Maglia, F.; Paschos, O.; Stiaszny, B. Future generations of cathode materials: An automotive industry perspective. J. Mater. Chem. A 2015, 3, 6709-6732. [CrossRef]

6. Placke, T.; Kloepsch, R.; Dühnen, S.; Winter, M. Lithium ion, lithium metal, and alternative rechargeable battery technologies: The odyssey for high energy density. J. Solid-State Electrochem. 2017, 21, 1939-1964. [CrossRef]

7. Zhang, X.; Xie, H.; Kim, C.-S.; Zaghib, K.; Mauger, A.; Julien, C.M. Advances in lithium-sulfur batteries. Mater. Sci. Eng. R Rep. 2017, 121, 1-29.

8. Mauger, A.; Julien, C.M.; Paollela, A.; Armand, M.; Zaghib, K. A comprehensive review of lithium salts and beyond for rechargeable batteries: Progress and perspectives. Mater. Sci. Eng. R Rep. 2018; in press.

9. Zaghib, K.; Mauger, A.; Julien, C.M. Rechargeable lithium batteries for energy storage in smart grids. In Rechargeable Lithium Batteries: From Fundamentals to Applications; Franco, A.A., Ed.; Woodhead Publ. Ltd.: Cambridge, UK, 2015; Chapter 12; pp. 319-351.

10. Manthiram, A.; Goodenough, J.B. Lithium insertion into $\mathrm{Fe}_{2}\left(\mathrm{SO}_{4}\right)_{3}$ frameworks. J. Power Sources 1989, 26, 403-408. [CrossRef]

11. Muraliganth, T.; Manthiram, A. Understanding the shifts in the redox potentials of olivine $\mathrm{LiM}_{1-\mathrm{y}} \mathrm{M}_{\mathrm{y}} \mathrm{PO}_{4}$ ( $\mathrm{M}=\mathrm{Fe}, \mathrm{Mn}, \mathrm{Co}$, and Mg) solid solution cathodes. J. Phys. Chem. C 2010, 114, 15530-15540. [CrossRef]

12. Li, Y.; Wang, C.; Gong, J. A wavelet transform-adaptive unscented Kalman filter approach for state of charge estimation of $\mathrm{LiFePO}_{4}$ battery. Int. J. Energy Res. 2018, 42, 587-600. [CrossRef]

13. Shen, Y. Supervised chaos genetic algorithm-based state of charge determination for $\mathrm{LiFePO}_{4}$ batteries in electric vehicles. AIP Conf. Proc. 2018, 1955, 040050.

14. Trudeau, M.L.; Laul, D.; Veillette, R.; Serventi, A.M.; Zaghib, K.; Mauger, A.; Julien, C.M. In-situ High-resolution transmission electron microscopy synthesis observation of nanostructured $\mathrm{LiFePO}_{4}$. J. Power Sources 2011, 196, 7383-7394. [CrossRef]

15. Rao, Y.; Wang, K.; Zeng, H. The effect of phenol-formaldehyde resin on the electrochemical properties of carbon-coated $\mathrm{LiFePO}_{4}$ materials in pilot scale. Ionics 2015, 21, 1525-1531. [CrossRef]

16. Wu, Y.; Zhou, L.; Xu, G.; Huang, J.; Fang, X.; Wang, Y.; Jin, Y.; Tang, X. Preparation of high tap density $\mathrm{LiFePO}_{4} / \mathrm{C}$ through carbothermal reduction process using beta-cyclodextrin as carbon Source. Int. J. Electrochem. Sci. 2018, 13, 2958-2968. [CrossRef]

17. Bhuvaneswari, D.; Kalaiselvi, N. In situ carbon coated $\mathrm{LiFePO}_{4} / \mathrm{C}$ microrods with improved lithium intercalation behavior. Phys. Chem. Chem. Phys. 2014, 16, 1469-1478. [CrossRef] [PubMed]

18. Wu, Y.; Wen, Z.; Feng, H.; Li, J. Sucrose-assisted loading of $\mathrm{LiFePO}_{4}$ nanoparticles on graphene for high-performance lithium-ion battery cathodes. Chem. Eur. J. 2013, 19, 5631-5636. [CrossRef] [PubMed]

19. Gong, C.; Xue, Z.; Wen, S.; Ye, Y.; Xie, X. Advanced carbon materials/olivine $\mathrm{LiFePO}_{4}$ composites cathode for lithium ion batteries. J. Power Sources 2016, 318, 93-112. [CrossRef]

20. Bazzi, K.; Mandal, B.P.; Nazri, M.; Naik, V.M.; Garg, V.K.; Oliveira, A.C.; Vaishnava, P.P.; Nazri, G.A.; Naik, R.; $\mathrm{Li}, \mathrm{Q}$. Effect of surfactants on the electrochemical behavior of $\mathrm{LiFePO}_{4}$ cathode material for lithium ion batteries. J. Power Sources 2014, 265, 67-74. [CrossRef]

21. Zheng, F.; Huang, Y.; Zhang, X.; Wu, Q.; Fu, D.; Zhang, J.; Yin, J.; Wang, H. Surfactants assisted synthesis of nano- $\mathrm{LiFePO}_{4} / \mathrm{C}$ composite as cathode materials for lithium-ion batteries. J. Mater. Chem. A 2015, 3, 2025-2035.

22. Gong, G.; Deng, F.; Tsui, C.P.; Xue, Z.; Ye, Y.S.; Tang, C.Y.; Zhou, X.; Xie, X. PANI-PEG copolymer modified $\mathrm{LiFePO}_{4}$ as a cathode material for high-performance lithium ion batteries. J. Mater. Chem. A 2014, 2, 19315-19323. [CrossRef]

23. Liu, Y.; Gu, J.; Zhang, J.; Yu, F.; Wang, J.; Nie, N.; Li, W. $\mathrm{LiFePO}_{4}$ nanoparticles growth with preferential (010) face modulated by Tween-80. RSC Adv. 2015, 5, 9745-9751. [CrossRef]

24. Xiong, Q.Q.; Lou, J.J.; Teng, X.J.; Lu, X.X.; Liu, S.Y.; Chi, H.Z.; Ji, Z.G. Controllable synthesis of N-C@LiFePO nanospheres as advanced cathode of lithium ion batteries. J. Alloy. Compd. 2018, 743, 377-382. [CrossRef] 
25. Li, Z.; Zhu, K.; Li, J.; Wang, X. Morphological and orientational diversity of $\mathrm{LiFePO}_{4}$ crystallites: Remarkable reaction path dependence in hydrothermal/solvothermal syntheses. CrystEngComm 2014, 16, 10112-10122. [CrossRef]

26. Cheng, F.; Wang, S.; Lu, A.; Yao, J. Immobilization of nanosized $\mathrm{LiFePO}_{4}$ spheres by $3 \mathrm{D}$ coralloid carbon structure with large pore volume and thin walls for high power lithium-ion batteries. J. Power Sources 2013, 229, 249-257. [CrossRef]

27. Jiang, Y.; Liao, S.; Liu, Z.; Xiao, G.; Liu, Q.; Song, H. High performance $\mathrm{LiFePO}_{4}$ microsphere composed with nanofibers with an alcohol-thermal approach. J. Mater. Chem. A 2013, 1, 4546-4551. [CrossRef]

28. Zhou, N.; Wang, H.-Y.; Uchaker, E.; Zhang, M.; Liu, S.Q.; Liu, Y.-N.; Cao, G. Additive-free solvothermal synthesis and Li-ion intercalation properties of dumbbell-shaped $\mathrm{LiFePO}_{4} / \mathrm{C}$ mesocrystals. J. Power Sources 2013, 239, 103-110. [CrossRef]

29. Ghafarian-Zahmatkesh, H.; Javanbakht, M.; Ghaemi, M. Ethylene-Glycol assisted hydrothermal synthesis and characterization of bow-tie-like lithium iron phosphate nanocrystals for lithium-ion batteries. J. Power Sources 2015, 284, 339-348. [CrossRef]

30. Zheng, Z.; Pang, W.K.; Tang, X.; Jia, D.; Huang, Y.; Guo, Z. Solvothermal synthesis and electrochemical performance of hollow $\mathrm{LiFePO}_{4}$ nanoparticles. J. Alloy. Compd. 2015, 640, 95-100. [CrossRef]

31. Song, J.; Wang, L.; Shao, G.; Shi, M.; Ma, Z.; Wang, G.; Song, W.; Liu, S.; Wang, C. Controllable synthesis, morphology evolution and electrochemical properties of $\mathrm{LiFePO}_{4}$ cathode materials for Li-ion batteries. Phys. Chem. Chem. Phys. 2014, 16, 7728-7733. [CrossRef] [PubMed]

32. Wang, Y.; Zhu, B.; Wang, Y.; Wang, F. Solvothermal synthesis of $\mathrm{LiFePO}_{4}$ nanorods as high-performance cathode materials for lithium ion batteries. Ceram. Int. 2016, 42, 10297-10303. [CrossRef]

33. Tian, R.; Liu, G.; Liu, H.; Zhang, L.; Gu, X.; Guo, Y.; Wang, H.; Sun, L.; Chu, W. Very high power and superior rate capability $\mathrm{LiFePO}_{4}$ nanorods hydrothermally synthesized using tetraglycol as surfactant. RSC Adv. 2015, 5, 1859-1866. [CrossRef]

34. Fisher, M.G.; Hua, X.; Wilts, B.D.; Castillo-Martinez, E.; Steiner, U. Polymer-templated $\mathrm{LiFePO}_{4} / \mathrm{C}$ nanonetworks as high-performance cathode materials for lithium-ion batteries. ACS Appl. Mater. Interfaces 2018, 10, 1646-1653. [CrossRef] [PubMed]

35. Qiu, Y.; Geng, Y.; Li, N.; Liu, X.; Zuo, X. Nonstoichiometric $\mathrm{LiFePO}_{4} / \mathrm{C}$ nanofibers by electrospinning as cathode materials for lithium-ion battery. Mater. Chem. Phys. 2014, 144, 226-229. [CrossRef]

36. Shao, D.; Wang, J.; Dong, X.; Yu, W.; Liu, G.; Zhang, F.; Wang, L. Electrospinning fabrication and electrochemical properties of $\mathrm{LiFePO}_{4} / \mathrm{C}$ composite nanofibers. J. Mater. Sci. Mater. Electron. 2013, 24, 4263-4269. [CrossRef]

37. Lin, H.Y.; Yeh, S.M.; Chen, J.S. Physical and electrochemical properties of $\mathrm{LiFePO}_{4} / \mathrm{C}$ nanofibers synthesized by electrospinning. Int. J. Electrochem. Sci. 2014, 9, 6936-6948.

38. Toprakci, O.; Ji, L.; Lin, Z.; Toprakci, H.A.K.; Zhang, X. Fabrication and electrochemical characteristics of electrospun $\mathrm{LiFePO}_{4}$ / carbon composite fibers for lithium-ion batteries. J. Power Sources 2011, 196, 7692-7699. [CrossRef]

39. Shao, D.; Wang, J.; Dong, X.; Yu, W.; Liu, G.; Zhang, F.; Wang, L. Preparation and electrochemical performances of $\mathrm{LiFePO}_{4} / \mathrm{C}$ composite nanobelts via facile electrospinning. J. Mater. Sci. Mater. Electron. 2014, 25, 1040-1046. [CrossRef]

40. Chen, L.L.; Shen, X.Q.; Jing, M.X.; Zhu, S.W.; Pi, Z.C.; Li, J.Q.; Zhai, H.A.; Xiao, K.S. Electrospun LiFePO 4 /C composite fiber membrane as a binder-free, self-standing cathode for power lithium-ion battery. J. Nanosci. Nano Technol. 2018, 18, 4720-4727. [CrossRef] [PubMed]

41. Bao, L.; Xu, G.; Sun, X.; Zeng, H.; Zhao, R.; Yang, X.; Shen, G.; Han, G.; Zhou, S. Mono-dispersed LiFePO $@^{@ C}$ core-shell [001] nanorods for a high power Li-ion battery cathode. J. Alloy. Compd. 2017, 708, 685-693. [CrossRef]

42. Xu, G.; Li, F.; Tao, Z.H.; Wei, X.; Liu, Y.; Li, X.; Ren, Z.H.; Shen, G.; Han, G.R. Monodispersed LiFePO $_{4} @ \mathrm{C}$ core-shell nanostructures for a high power Li-ion battery cathode. J. Power Sources 2014, 246, 696-702. [CrossRef]

43. Yuan, H.; Wang, X.Y.; Wu, Q.; Shu, H.B.; Yang, X.K. Effects of Ni and Mn doping on physicochemical and electrochemical performances of $\mathrm{LiFePO}_{4}$ /C. J. Alloy. Compd. 2016, 675, 187-194. [CrossRef]

44. Saravanan, K.; Vittal, J.J.; Reddy, M.V.; Chowdari, B.V.R.; Balaya, P. Storage performance of $\mathrm{Li}_{1-\mathrm{x}} \mathrm{Mn}_{\mathrm{x}} \mathrm{PO}_{4}$ nanoplates ( $\mathrm{x}=0$, 0.5, and 1). J. Solid State Electrochem. 2010, 23, 1933-1947. 
45. Saravanan, K.; Reddy, M.V.; Balaya, P.; Gong, H.; Chowdari, B.V.R.; Vittal, J.J. Storage performance of $\mathrm{LiFePO}_{4}$ nanoplates. J. Mater. Chem. 2009, 19, 605-610. [CrossRef]

46. Saravanan, K.; Balaya, P.; Reddy, M.V.; Chowdari, B.V.R.; Vittal, J.J. Morphology controlled synthesis of $\mathrm{LiFePO}_{4} / \mathrm{C}$ nanoplates for Li-ion batteries. Energy Environ. Sci. 2010, 3, 457-464. [CrossRef]

47. Schmuch, R.; Wagner, R.; Hörpel, G.; Placke, T.; Winter, M. Performance and cost of materials for lithium-based rechargeable automotive batteries. Nat. Energy 2018, 3, 267-278. [CrossRef]

48. Benedek, P.; Wenzler, N.; Yarema, M.; Wood, V.C. Low temperature hydrothermal synthesis of battery grade lithium iron phosphate. RSC Adv. 2017, 7, 17763. [CrossRef]

49. Yang, J.L.; Wang, J.J.; Tang, Y.J.; Wang, D.N.; Li, X.F.; Hu, Y.H.; Li, R.Y.; Liang, G.X.; Sham, T.K.; Sun, X.L. $\mathrm{LiFePO}_{4}$-graphene as a superior cathode material for rechargeable lithium batteries: Impact of stacked graphene and unfolded graphene. Energy Environ. Sci. 2013, 6, 1521-1528. [CrossRef]

50. Jegal, J.P.; Kim, K.C.; Kim, M.S.; Kim, K.B. A lithium iron phosphate/nitrogen-doped reduced graphene oxide nanocomposite as a cathode material for high-power lithium ion batteries. J. Mater. Chem. A 2014, 2, 9594-9599. [CrossRef]

51. Wu, H.X.; Liu, Q.J.; Guo, S.W. Composites of graphene and $\mathrm{LiFePO}_{4}$ as cathode materials for lithium-ion battery: A mini-review. Nano-Micro Lett. 2014, 6, 316-326. [CrossRef]

52. Wang, Z.Z.; Guo, H.-F.; Yan, P. A rapid microwave heating route to synthesize graphene modified $\mathrm{LiFePO}_{4} / \mathrm{C}$ nanocomposite for rechargeable lithium-ion batteries. Ceram. Int. 2014, 40, 15801-15806. [CrossRef]

53. Zhou, X.; Wang, F.; Zhu, Y.; Liu, Z. Graphene modified $\mathrm{LiFePO}_{4}$ cathode materials for high power lithium ion batteries. J. Mater. Chem. 2011, 21, 3353-3358. [CrossRef]

54. Shang, W.L.; Kong, L.Y.; Ji, X.W. Synthesis, characterization and electrochemical performances of $\mathrm{LiFePO}_{4}$ /graphene cathode material for high power lithium-ion batteries. Solid State Sci. 2014, 38, 79-84. [CrossRef]

55. Kucinskis, G.; Bajars, G.; Kleperis, J. Graphene in lithium ion battery cathode materials: A review. J. Power Sources 2013, 240, 66-79. [CrossRef]

56. Mo, R.W.; Lei, Z.Y.; Rooney, D.; Sun, K.N. Facile synthesis of nanocrystalline $\mathrm{LiFePO}_{4} /$ graphene composite as cathode material for high power lithium ion batteries. Electrochim. Acta 2014, 130, 594-599. [CrossRef]

57. Wang, B.; Wang, S.; Liu, P.; Deng, J.; Xu, B.H.; Liu, T.F.; Wang, D.L.; Zhao, X.S. Growth of $\mathrm{LiFePO}_{4}$ nanoplatelets with orientated (010) facets on graphene for fast lithium storage. Mater. Lett. 2014, 118, 137-141. [CrossRef]

58. Long, Y.; Shu, Y.; Ma, X.; Ye, M. In-situ synthesizing superior high-rate $\mathrm{LiFePO}_{4} / \mathrm{C}$ nanorods embedded in graphene matrix. Electrochim. Acta 2014, 117, 105-112. [CrossRef]

59. Xu, H.; Chang, J.; Sun, J.; Gao, L. Graphene-encapsulated $\mathrm{LiFePO}_{4}$ nanoparticles with high electrochemical performance for lithium ion batteries. Mater. Lett. 2012, 83, 27-30. [CrossRef]

60. Zhang, Y.; Wang, W.C.; Li, P.H.; Fu, Y.B.; Ma, X.H. A simple solvothermal route to synthesize graphene-modified $\mathrm{LiFePO}_{4}$ cathode for high power lithium ion batteries. J. Power Sources 2012, 210, 47-53. [CrossRef]

61. Fathollahi, F.; Javanbakht, M.; Omidvar, H.; Ghaemi, M. Improved electrochemical properties of $\mathrm{LiFePO}_{4}$ /graphene cathode nanocomposite prepared by one-step hydrothermal method. J. Alloy. Compd. 2015, 627, 146-152. [CrossRef]

62. Tang, Y.F.; Huang, F.Q.; Bi, H.; Liu, Z.Q.; Wan, D.-Y. Highly conductive three-dimensional graphene for enhancing the rate performance of $\mathrm{LiFePO}_{4}$ cathode. J. Power Sources 2012, 203, 130-134. [CrossRef]

63. Wang, Y.; Feng, Z.-S.; Chen, J.-J.; Zhang, C. Synthesis and electrochemical performance of $\mathrm{LiFePO}_{4} /$ graphene composites by solid-state reaction. Mater. Lett. 2012, 71, 54-56. [CrossRef]

64. Wu, K.; Hu, G.; Du, K.; Peng, Z.; Cao, Y. Improved electrochemical properties of $\mathrm{LiFePO}_{4} /$ graphene/carbon composite synthesized from $\mathrm{FePO}_{4} \cdot 2 \mathrm{H}_{2} \mathrm{O}$ /graphene oxide. Ceram. Int. 2015, 41, 13867-13871. [CrossRef]

65. Wang, B.; Liu, A.; Abdulla, W.A.; Wang, D.; Zhao, X.S. Desired crystal oriented $\mathrm{LiFePO}_{4}$ nanoplatelets in situ anchored on a graphene cross-linked conductive network for fast lithium storage. Nanoscale 2015, 7, 8819-8828. [CrossRef] [PubMed]

66. Wang, X.; Feng, Z.; Huang, J.; Deng, W.; Li, X.; Zhang, H.; Wen, Z. Graphene-decorated carbon-coated $\mathrm{LiFePO}_{4}$ nanospheres as a high-performance cathode material for lithium-ion batteries. Carbon 2018, 127, 149-157. [CrossRef] 
67. Tian, X.; Zhou, Y.; Tu, X.; Zhang, Z.; Du, G. Well-dispersed $\mathrm{LiFePO}_{4}$ nanoparticles anchored on a three-dimensional graphene aerogel as high-performance positive electrode materials for lithium-ion batteries. J. Power Sources 2017, 340, 40-50. [CrossRef]

68. Yang, J.L.; Wang, J.J.; Wang, D.N.; Li, X.F.; Geng, D.S.; Liang, G.X.; Gauthier, M.; Li, R.Y.; Sun, X.L. 3D porous $\mathrm{LiFePO}_{4}$ /graphene hybrid cathodes with enhanced performance for Li-ion batteries. J. Power Sources 2012, 208, 340-344. [CrossRef]

69. Li, X.L.; Li, T.T.; Zhang, Y.L.; Zhang, X.L.; Li, H.Y.; Huang, J.M. Graphene nanoribbon-wrapping LiFePO $_{4}$ by electrostatic absorbing with improved electrochemical performance for rechargeable lithium batteries. Electrochim. Acta 2014, 139, 69-75. [CrossRef]

70. Wu, G.; Ran, R.; Zhao, B.T.; Sha, Y.J.; Su, C.; Zhou, Y.K.; Shao, Z.P. 3D amorphous carbon and graphene co-modified $\mathrm{LiFePO}_{4}$ composite derived from polyol process as electrode for high power lithium-ion batteries. J. Energy Chem. 2014, 23, 363-375. [CrossRef]

71. Wei, X.; Guan, Y.; Zheng, X.; Zhu, Q.; Shen, J.; Qiao, N.; Zhou, S.; Xu, B. Improvement on high rate performance of $\mathrm{LiFePO}_{4}$ cathodes using graphene as a conductive agent. Appl. Surf. Sci. 2018, 440, 748-754. [CrossRef]

72. Eftekhari, A. $\mathrm{LiFePO}_{4} / \mathrm{C}$ nanocomposites for lithium-ion batteries. J. Power Sources 2017, 343, $395-411$. [CrossRef]

73. Mei, R.; Yang, Y.; Song, X.; An, Z.; Zhang, J. Triple carbon coated $\mathrm{LiFePO}_{4}$ composite with hierarchical conductive architecture as high-performance cathode for Li-ion batteries. Electrochim. Acta 2015, 153, 523-550. [CrossRef]

74. Chen, Y.T.; Zhang, H.Y.; Chen, Y.M.; Qin, G.; Lei, X.L.; Liu, L.Y. Graphene-carbon nanotubes-modified $\mathrm{LiFePO}_{4}$ cathode materials for high-performance lithium-ion batteries. Mater. Sci. Forum 2018, 913, 818-830. [CrossRef]

75. Wu, R.; Xia, G.; Shen, S.; Zhu, F.; Jiang, F.; Zhang, J. In-situ growth of $\mathrm{LiFePO}_{4}$ nanocrystals on interconnected carbon nanotubes / mesoporous carbon nanosheets for high-performance lithium ion batteries. Electrochim. Acta 2015, 153, 334-342. [CrossRef]

76. Qian, J.; Zhou, M.; Cao, Y.; Ai, X.; Yang, H. Template-free hydrothermal synthesis of nanoembossed mesoporous $\mathrm{LiFePO}_{4}$ microspheres for high-performance lithium-ion batteries. J. Phys. Chem. C 2010, 114, 3477-3482. [CrossRef]

77. Sun, C.; Rajasekhara, S.; Goodenough, J.B.; Zhou, F. Monodisperse porous $\mathrm{LiFePO}_{4}$ microspheres for a high power Li-ion battery cathode. J. Am. Chem. Soc. 2011, 133, 2132-2135. [CrossRef] [PubMed]

78. Cho, M.-Y.; Kim, K.-B.; Lee, J.-W.; Kim, H.; Kim, H.; Kang, K.; Roh, K.C. Defect-free solvothermally assisted synthesis of microspherical mesoporous $\mathrm{LiFePO}_{4} / \mathrm{C}$. RSC Adv. 2013, 3, 3421-3427. [CrossRef]

79. Ni, L.; Zheng, J.; Qin, C.; Lu, Y.; Liu, P.; Wu, T.; Tang, Y.; Chen, Y. Fabrication and characteristics of spherical hierarchical $\mathrm{LiFePO}_{4} / \mathrm{C}$ cathode material by a facile method. Electrochim. Acta 2014, 147, 330-336. [CrossRef]

80. Kulka, A.; Braun, A.; Huang, T.W.; Wolska, A.; Klepka, M.T.; Szewczyk, A.; Baster, D.; Zajac, W.; Swierczek, K.; Molenda, J. Evidence for Al doping in lithium sublattice of $\mathrm{LiFePO}_{4}$. Solid State Ion. 2015, 270, 33-38. [CrossRef]

81. Zaghib, K.; Mauger, A.; Goodenough, J.B.; Gendron, F.; Julien, C.M. Electronic, optical, and magnetic properties of $\mathrm{LiFePO}_{4}$ : small magnetic polaron effects. Chem. Mater. 2007, 19, 3740-3747. [CrossRef]

82. Islam, M.S.; Driscoll, D.J.; Fisher, C.A.J.; Slater, P.R. Atomic-scale investigation of defects, dopants, and lithium transport in the $\mathrm{LiFePO}_{4}$ olivine-type battery material. Chem. Mater. 2005, 17, 5085-5092. [CrossRef]

83. Wagemaker, M.; Ellis, B.L.; Lutzenkirchen-Hecht, D.; Mulder, F.M.; Nazar, L.F. Proof of supervalent doping in olivine $\mathrm{LiFePO}_{4}$. Chem. Mater. 2008, 20, 6313-6315. [CrossRef]

84. Omenya, F.; Chernova, N.A.; Upreti, S.; Zavalij, P.Y.; Nam, K.-W.; Yang, X.-Q.; Whittingham, M.S. Can vanadium be substituted into $\mathrm{LiFePO}_{4}$ ? Chem. Mater. 2011, 23, 4733-4740. [CrossRef]

85. Harrison, K.; Bridges, C.A.; Paranthaman, M.P.; Segre, C.U.; Katsoudas, J.; Maroni, V.A.; Idrobo, J.C.; Goodenough, J.B.; Manthiram, A. Temperature dependence of aliovalent-vanadium doping in $\mathrm{LiFePO}_{4}$ cathodes. Chem. Mater. 2013, 25, 768-781. [CrossRef]

86. Wu, T.; Liu, J.; Sun, L.; Cong, L.; Xie, H.; Abdel-Ghany, A.; Mauger, A.; Julien, C.M. V-insertion in $\mathrm{Li}(\mathrm{Fe}, \mathrm{Mn}) \mathrm{FePO}_{4}$. J. Power Sources 2018, 383, 133-143. [CrossRef] 
87. Chiang, C.Y.; Su, H.C.; Wu, P.J.; Liu, H.J.; Hu, C.W.; Sharma, N.; Peterson, V.K.; Hsieh, H.W.; Lin, Y.F.; Chou, W.C.; et al. Vanadium substitution of $\mathrm{LiFePO}_{4}$ cathode materials to enhance the capacity of $\mathrm{LiFePO}_{4}$-based lithium-ion batteries. J. Phys. Chem. C 2012, 116, 24424-24429. [CrossRef]

88. Axmann, P.; Stinner, C.; Wohlfahrt-Mehrens, M.; Mauger, A.; Gendron, F.; Julien, C.M. Non-stoichiometric $\mathrm{LiFePO}_{4}$ : Defects and related properties. Chem. Mater. 2009, 21, 1636-1644. [CrossRef]

89. Zaghib, K.; Mauger, A.; Goodenough, J.B.; Gendron, F.; Julien, C.M. Design and properties of LiFePO electrode materials for Li-ion batteries. In Advanced Materials and Methods for Lithium batteries; Zhang, S.S., Ed.; Research Signpost: Trivandrum, India, 2007; Chapter 6; pp. 115-149.

90. Zaghib, K.; Mauger, A.; Goodenough, J.B.; Gendron, F.; Julien, C.M. Positive electrode: Lithium iron phosphate. In Encyclopedia of Electrochemical Power Sources; Garche, J., Ed.; Elsevier: Amsterdam, The Netherlands, 2009; pp. 264-296.

91. Zhang, L.; Tang, Y.; Liu, Z.; Huang, H.; Fang, Y.; Huang, F. Synthesis of $\mathrm{Fe}_{2} \mathrm{P}$ coated $\mathrm{LiFePO}_{4}$ nanorods with enhanced Li-storage performance. J. Alloy. Compd. 2015, 627, 132-135. [CrossRef]

92. Mauger, A.; Julien, C.M. Surface modifications of electrode materials for lithium-ion batteries: Status and trends. Ionics 2014, 20, 751-787. [CrossRef]

93. Zaghib, K.; Mauger, A.; Julien, C.M. Overview of olivines in lithium batteries for green transportation and energy storage. J. Solid State Electrochem. 2012, 16, 835-845. [CrossRef]

94. Halankar, K.K.; Mandal, B.P.; Jangid, M.; Mukhopadhyay, A.; Meena, S.S.; Acharya, R.; Tyagi, A.K. Optimization of lithium content in $\mathrm{LiFePO}_{4}$ for superior electrochemical performance: The role of impurities. RSC Adv. 2018, 8, 1140-1147. [CrossRef]

95. Lin, Y.; Lin, Y.; Zhou, T.; Zhao, G.; Huang, Y.; Huang, Z. Enhanced electrochemical performances of $\mathrm{LiFePO}_{4} / \mathrm{C}$ by surface modification with Sn nanoparticles. J. Power Sources 2013, 226, 20-26. [CrossRef]

96. Zaghib, K.; Dontigny, M.; Guerfi, A.; Trottier, J.; Hamel-Paquet, J.; Gariepy, V.; Galoutov, K.; Hovington, P.; Mauger, A.; Groult, $\mathrm{H}$;; et al. An improved high-power battery with increased thermal operating range: $\mathrm{C}-\mathrm{LiFePO}_{4} / / \mathrm{C}-\mathrm{Li}_{4} \mathrm{Ti}_{5} \mathrm{O}_{12}$. J. Power Sources 2012, 216, 192-200. [CrossRef]

97. Yamada, A.; Koizumi, H.; Sonoyama, N.; Kanno, R. Phase change in $\mathrm{Li}_{\mathrm{x}} \mathrm{FePO}_{4}$. Electrochem. Solid-State Lett. 2005, 8, A409-A413. [CrossRef]

98. Ramana, C.V.; Mauger, A.; Gendron, F.; Julien, C.M.; Zaghib, K. Study of the Li-insertion/extraction process in $\mathrm{LiFePO}_{4} / \mathrm{FePO}_{4}$. J. Power Sources 2009, 187, 555-564. [CrossRef]

99. Bai, P.; Cogswell, D.A.; Bazant, M.Z. Suppression of phase separation in $\mathrm{LiFePO}_{4}$ nanoparticles during battery discharge. Nano Lett. 2011, 11, 4890-4896. [CrossRef] [PubMed]

100. Liu, H.; Strobridge, F.C.; Borkiewicz, O.J.; Wiaderek, K.M.; Chapman, K.W.; Chupas, P.J.; Grey, C.P. Capturing metastable structures during high-rate cycling of $\mathrm{LiFePO}_{4}$ nanoparticle electrodes. Science 2014, 344, 1252817. [CrossRef] [PubMed]

101. Kuss, C.; Lepage, D.; Liang, G.; Schougaard, S.B. Ultrafast charging of $\mathrm{LiFePO}_{4}$ with gaseous oxidants under ambient conditions. Chem. Sci. 2013, 4, 4423-4427. [CrossRef]

102. Kuss, C.; Trinh, N.D.; Andjelic, S.; Saulnier, M.; Dufresne, E.M.; Liang, G.; Schougaard, S.B. Structural transformation of $\mathrm{LiFePO}_{4}$ during ultrafast delithiation. Phys. Chem. Lett. 2017, 8, 6160-6164. [CrossRef] [PubMed]

103. Liu, Q.; Liu, Y.; Yang, F.; He, H.; Xiao, X.; Ren, Y.; Lu, W.; Stach, E.; Xie, J. Capacity fading mechanism of the commercial $18650 \mathrm{LiFePO}_{4}$-based lithium-ion batteries: An in situ time-resolved high-energy synchrotron XRD study. ACS Appl. Mater. Interfaces 2018, 10, 4622-4629. [CrossRef] [PubMed]

104. Panasonic Batteries. Available online: http://www.meircell.co.il/files/NCR18650A\%20datasheet.pdf (accessed on 7 July 2018).

105. Zhao, J.; Gao, Y.; Guo, J.; Chu, L.; Burke, A.F. Cycle life testing of lithium batteries: The effect of load-leveling. Int. J. Electrochem. Sci. 2018, 13, 1773-1786. [CrossRef]

106. Rissouli, K.; Benkhouja, K.; Ramos-Barrado, J.R.; Julien, C.M. Electrical conductivity in lithium orthophosphates. Mater. Sci. Eng. B 2003, 98, 185-189. [CrossRef]

107. Bramnik, N.N.; Ehrenberg, H. Precursor-based synthesis and electrochemical performance of $\mathrm{LiMnPO}_{4}$. J. Alloy. Compd. 2008, 464, 259-264. [CrossRef]

108. Di Lecce, D.; Hu, T.; Hassoun, J. Electrochemical features of $\mathrm{LiMnPO}_{4}$ olivine prepared by sol-gel pathway. J. Alloy. Compd. 2017, 693, 730-737. [CrossRef] 
109. Choi, D.; Wan, D.; Bae, L.T.; Xiao, J.; Nie, Z.; Wang, W.; Viswanathan, V.V.; Lee, Y.J.; Zhang, J.G.; Graff, G.L.; et al. $\mathrm{LiMnPO}_{4}$ nanoplate grown via solid-state reaction in molten hydrocarbon for Li-ion battery cathode. Nano Lett. 2010, 10, 2799-2805. [CrossRef] [PubMed]

110. Oh, S.M.; Oh, S.W.; Yoon, C.S.; Scrosati, B.; Amine, K.; Sun, Y.K. High-performance carbon-LiMnPO 4 nanocomposite cathode for lithium batteries. Adv. Funct. Mater. 2010, 20, 3260-3265. [CrossRef]

111. Fujimoto, D.; Lei, Y.; Huang, Z.-H.; Kang, F.; Kawamura, J. Synthesis and electrochemical performance of $\mathrm{LiMnPO}_{4}$ by hydrothermal method. Int. J. Electrochem. 2014, 2014, 768912. [CrossRef]

112. Wu, Z.; Huang, R.R.; Xie, Y.C.; Lv, X.Y.; Su, J.; Long, Y.F.; Wen, Y.X. Deep eutectic solvent synthesis of $\mathrm{LiMnPO}_{4} / \mathrm{C}$ nanorods as a cathode material for lithium Ion batteries. Materials 2017, 10, 134. [CrossRef] [PubMed]

113. Wu, Z.; Long, Y.F.; Lv, X.Y.; Su, J.; Wen, Y.X. Microwave heating synthesis of spindle-like $\mathrm{LiMnPO}_{4} / \mathrm{C}$ in a deep eutectic solvent. Ceram. Int. 2017, 43, 6089-6095. [CrossRef]

114. Lu, X.; Wang, X.; Wang, M.; Fang, H. Cycling stability of $\mathrm{LiMnPO}_{4} / \mathrm{C}$ composite obtained by different processing routes. Int. J. Electrochem. Sci. 2017, 12, 2909-2916. [CrossRef]

115. Kwon, N.H.; Yin, H.; Vavrova, T.; Lim, J.H.-W.; Steiner, U.; Grobéty, B.; Fromm, K.M. Nanoparticle shapes of $\mathrm{LiMnPO}_{4}$, Li-diffusion orientation and diffusion coefficients for high volumetric energy Li-ion cathodes. J. Power Sources 2017, 342, 231-240. [CrossRef]

116. Wang, D.; Buqa, H.; Crouzet, M.; Deghenghi, G.; Drezen, T.; Exnar, I.; Kwon, N.H.; Miners, J.; Poletto, L.; Gratzel, M. High-performance nano-structured $\mathrm{LiMnPO}_{4}$ synthesized via a polyol method. J. Power Sources 2009, 189, 624-628. [CrossRef]

117. Martha, S.K.; Markovsky, B.; Grinblat, J.; Gofer, Y.; Haik, O.; Zinigrad, E.; Aurbach, D.; Drezen, T.; Wang, D.; Deghenghi, G.; et al. $\mathrm{LiMnPO}_{4}$ as an advanced cathode material for rechargeable lithium batteries. J. Electrochem. Soc. 2009, 156, A541-A552. [CrossRef]

118. Long, Y.; Zhang, Z.; Wu, Z.; Su, J.; Lv, X.; Wen, Y. Microwave-assisted polyol synthesis of $\mathrm{LiMnPO}_{4} / \mathrm{C}$ and its use as a cathode material in lithium-ion batteries. Particuology 2017, 33, 42-49. [CrossRef]

119. Kumar, P.R.; Venkateswarlu, M.; Misra, M.; Mohanty, A.K.; Satyanarayana, N. Carbon coated $\mathrm{LiMnPO}_{4}$ nanorods for lithium batteries. J. Electrochem. Soc. 2011, 158, A227-A230. [CrossRef]

120. Pivko, M.; Bele, M.; Tchernychova, E.; Logar, Z.; Dominko, R.; Gaberscek, M. Synthesis of nanometric $\mathrm{LiMnPO}_{4}$ via a two-step technique. Chem. Mater. 2012, 24, 1041-1047. [CrossRef]

121. Guo, H.; Wu, C.; Xie, J.; Zhang, S.; Cao, G.; Zhao, X. Controllable synthesis of high-performance $\mathrm{LiMnPO}_{4}$ nanocrystals by a facile one-spot solvothermal process. J. Mater. Chem. A 2014, 2, 10581-10588. [CrossRef]

122. Julien, C.M.; Zaghib, K.; Mauger, A.; Massot, M.; Ait-Salah, A.; Selmane, M.; Gendron, F. Characterization of the carbon-coating of $\mathrm{LiFePO}_{4}$ by transmission electron microscopy and Raman spectroscopy. J. Appl. Phys. 2006, 100, 063511. [CrossRef]

123. Ravet, N.; Gauthier, M.; Zaghib, K.; Mauger, A.; Goodenough, J.B.; Gendron, F.; Julien, C.M. Mechanism of the $\mathrm{Fe}^{2+}$ reduction at low temperature, for $\mathrm{LiFePO}_{4}$ synthesis from a polymer additive. Chem. Mater. 2007, 19, 2595-2602. [CrossRef]

124. Mizuno, Y.; Kotobuki, M.; Munakata, H.; Kanamura, K. Effect of carbon source on electrochemical performance of carbon coated $\mathrm{LiMnPO}_{4}$ cathode. J. Ceram. Soc. Jpn. 2009, 117, 1225-1228. [CrossRef]

125. Li, L.E.; Liu, J.; Chen, L.; Xu, H.; Yang, J.; Qian, Y. Effect of different carbon sources on the electrochemical properties of rod-like $\mathrm{LiMnPO}_{4} / \mathrm{C}$ nanocomposites. RSC Adv. 2013, 3, 6847-6852. [CrossRef]

126. Fan, J.; Yu, Y.; Wang, Y.; Wu, Q.H.; Zheng, M.; Dong, Q. Nonaqueous synthesis of nano-sized $\mathrm{LiMnPO}_{4} @ \mathrm{C}$ as a cathode material for high performance lithium ion batteries. Electrochim. Acta 2016, 194, 52-58. [CrossRef]

127. Moon, S.; Muralidharan, P.; Kim, D.K. Carbon coating by high-energy milling and electrochemical properties of $\mathrm{LiMnPO}_{4}$ obtained in polyol process. Ceram. Int. 2012, 38, S471-S475. [CrossRef]

128. Liu, J.L.; Hu, D.G.; Huang, T.; Yu, A.S. Synthesis of flower-like $\mathrm{LiMnPO}_{4} / \mathrm{C}$ with precipitated $\mathrm{NH}_{4} \mathrm{MnPO}_{4} \cdot \mathrm{H}_{2} \mathrm{O}$ as precursor. J. Alloy. Compd. 2012, 518, 58-62. [CrossRef]

129. Aono, S.; Urita, K.; Yamada, H.; Moriguchi, I. Rapid synthesis and charge-discharge properties of $\mathrm{LiMnPO}_{4}$ nanocrystallite-embedded porous carbons. Chem. Lett. 2012, 41, 162-164. [CrossRef]

130. Doan, N.L.; Taniguchi, I. Cathode performance of $\mathrm{LiMnPO}_{4} / \mathrm{C}$ nanocomposites prepared by a combination of spray pyrolysis and wet ball-milling followed by heat treatment. J. Power Sources 2011, 196, 1399-1408. [CrossRef] 
131. Wang, F.; Yang, J.; Gao, P.F.; Li, Y.N.; Wang, J.L. Morphology regulation and carbon coating of $\mathrm{LiMnPO}_{4}$ cathode material for enhanced electrochemical performance. J. Power Sources 2011, 196, 10258-10262. [CrossRef]

132. Zhao, M.; Fu, Y.; Xu, N.; Li, G.; Wu, M.; Gao, X. High performance $\mathrm{LiMnPO}_{4} / \mathrm{C}$ prepared by a crystallite size control method. J. Mater. Chem. A 2014, 2, 15070-15077. [CrossRef]

133. Koleva, A.; Zhecheva, E.; Stoyanova, R. A new phosphate-formate precursor method for the preparation of carbon coated nano-crystalline $\mathrm{LiFePO}_{4}$. J. Alloy. Compd. 2009, 476, 950-957. [CrossRef]

134. Koleva, V.; Stoyanova, R.; Zhecheva, E. Nano-crystalline $\mathrm{LiMnPO}_{4}$ prepared by a new phosphate-formate precursor method. Mater. Chem. Phys. 2010, 121, 370-377. [CrossRef]

135. Su, K.; Liu, F.; Chen, J.T. Preparation of high performance carbon-coated $\mathrm{LiMnPO}_{4}$ nanocomposite by an acetate-assisted antisolvent precipitation method. J. Power Sources 2013, 232, 234-239. [CrossRef]

136. Dinh, H.C.; Mho, S.I.; Kang, Y.K.; Yeo, I.H. Large discharge capacities at high current rates for carbon-coated $\mathrm{LiMnPO}_{4}$ nanocrystalline cathodes. J. Power Sources 2013, 244, 189-195. [CrossRef]

137. Tang, Y.H.; Tang, Z.; Wang, S.; Quan, W.; Zhang, Z. High-performance $\mathrm{LiMnPO}_{4}$ nanorods synthesized via a facile EG-assisted solvothermal approach. J. Mater. Chem. 2015, 3, 10267-10274.

138. Zheng, X.; Huang, B.; Fan, X.; Song, G.; Lu, M. Enhanced rate performance of nano-micro structured $\mathrm{LiFePO}_{4} / \mathrm{C}$ by improved process for high-power Li-ion batteries. Electrochim. Acta 2011, 56, 4865-4868.

139. Wang, Y.; He, P.; Zhou, H. $\mathrm{LiFePO}_{4}$ : Development and future. Energy Environ. Sci. 2011, 4, 805-817. [CrossRef]

140. Duan, J.; Cao, Y.; Jiang, J.; Du, K.; Peng, Z.; Hu, G. Novel efficient synthesis of nanosized carbon coated $\mathrm{LiMnPO}_{4}$ composite for lithium ion batteries and its electrochemical performance. J. Power Sources 2014, 268, 146-152. [CrossRef]

141. Fan, C.F.; Barai, P.; Mukherjee, P.P. Diffusion induced damage and impedance response in lithium-ion battery electrodes. J. Electrochem. Soc. 2014, 161, A2138-A2152.

142. Norberg, N.S.; Kostecki, R. The degradation mechanism of a composite $\mathrm{LiMnPO}_{4}$ cathode. J. Electrochem. Soc. 2012, 159, A1431-A1434. [CrossRef]

143. Moskon, J.; Pivko, M.; Jerman, I.; Tchernychova, E.; Zabukovec-Logar, M.; Zorko, N.; Selih, V.S.; Dominko, R.; Gaberscek, M. Cycling stability and degradation mechanism of $\mathrm{LiMnPO}_{4}$ based electrodes. J. Power Sources 2016, 303, 97-108. [CrossRef]

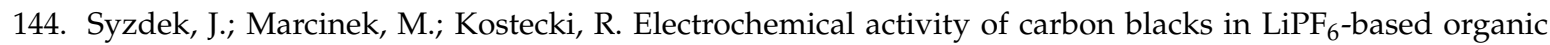
electrolytes. J. Power Sources 2014, 245, 739-744. [CrossRef]

145. Zhang, Z.; Hu, G.; Cao, Y.; Duan, J.; Du, K.; Peng, Z. Enhanced electrochemical performance of nano $\mathrm{LiMnPO}_{4}$ with multifunctional surface co-coating of $\mathrm{Li}_{2} \mathrm{TiO}_{3}$ and carbon. Solid State Ion. 2015, 283, 115-122. [CrossRef]

146. Wang, Y.; Wang, F.; Feng, X. Porous nest-like $\mathrm{LiMnPO}_{4}$ microstructures assembled by nanosheets for lithium ion battery cathodes. J. Mater. Sci. Mater. Electron. 2018, 29, 1426-1434. [CrossRef]

147. Ramar, V.; Saravanan, K.; Gajjela, S.R.; Harihran, S.; Balaya, P. The effect of synthesis parameters on the lithium storage performance of $\mathrm{LiMnPO}_{4} / \mathrm{C}$. Electrochim. Acta 2013, 105, 496-505. [CrossRef]

148. Hu, X.; Sun, X.; Yang, M.; Ji, H.; Li, X.; Cai, S.; Guo, R.; Hou, F.; Zheng, C.; Hu, W. Sandwich nanostructured $\mathrm{LiMnPO}_{4} / \mathrm{C}$ as enhanced cathode materials for lithium-ion batteries. J. Mater. Sci. 2017, 52, 3597-3612. [CrossRef]

149. Fang, H.; Yi, H.; Hu, C.; Yang, B.; Yao, Y.; Ma, W.; Dai, Y. Effect of Zn doping on the performance of $\mathrm{LiMnPO}_{4}$ cathode for lithium ion batteries. Electrochim. Acta 2012, 71, 266-269. [CrossRef]

150. Wang, Y.R.; Chen, Y.F.; Cheng, S.Q.; He, L.N. Improving electrochemical performance of $\mathrm{LiMnPO}_{4}$ by $\mathrm{Zn}$ doping using a facile solid state method. Korean J. Chem. Eng. 2011, 28, 964-968. [CrossRef]

151. Shiratsuchi, T.; Okada, S.; Doi, T.; Yamaki, J.I. Cathodic performance of $\mathrm{LiMn}_{1-x} \mathrm{M}_{x} \mathrm{PO}_{4}(M=\mathrm{Ti}, \mathrm{Mg}$ and $\mathrm{Zr})$ annealed in an inert atmosphere. Electrochim. Acta 2009, 54, 3145-3151. [CrossRef]

152. Ni, J.; Gao, L. Effect of copper doping on $\mathrm{LiMnPO}_{4}$ prepared via hydrothermal route. J. Power Sources 2011, 196, 6498-6501. [CrossRef]

153. Kou, L.Q.; Chen, F.J.; Tao, F.; Dong, Y.; Chen, L. High rate capability and cycle performance of Ce-doped $\mathrm{LiMnPO}_{4} / \mathrm{C}$ via an efficient solvothermal synthesis in water/diethylene glycol system. Electrochim. Acta 2015, 173, 721-727. [CrossRef] 
154. Verma, S.; Bamzai, K.K. Preparation of cerium orthophosphate nanosphere by coprecipitation route and its structural, thermal, optical, and electrical characterization. J. Nanopart. 2014, 2014, 125360. [CrossRef]

155. Gan, Y.; Chen, C.; Liu, J.; Bian, P.; Hao, H.; Yu, A. Enhancing the performance of $\mathrm{LiMnPO}_{4} / \mathrm{C}$ composites through Cr doping. J. Alloy. Compd. 2015, 620, 350-357. [CrossRef]

156. Kellerman, D.G.; Chukalkin, Y.G.; Mukhina, N.A.; Gorshkov, V.S.; Semenova, A.S.; Teplykh, A.E. Some aspects of antiferromagnetic ordering in $\mathrm{LiMnP}_{0.85} \mathrm{~V}_{0.15} \mathrm{O}_{4}$ : Neutron diffraction and DC-magnetization studies. J. Magn. Magn. Mater. 2012, 324, 3181-3188. [CrossRef]

157. Kellerman, D.G.; Chukalkin, Y.G.; Medvedeva, N.I.; Kuznetsov, M.V.; Mukhina, N.A.; Semenova, A.S.; Gorshkov, V.S. Hydrogen reduction of vanadium in vanadium-doped $\mathrm{LiMnPO}_{4}$. Mater. Chem. Phys. 2015, 149-150, 209-215. [CrossRef]

158. Mauger, A.; Ferré, J.; Beauvillain, P. Scaling of the non-linear magnetic susceptibility in the spin glass CdMnTe. Phys. Rev. B 1989, 40, 862. [CrossRef]

159. Clemens, O.; Bauer, M.; Haberkorn, R.; Springborg, M.; Philipp, H. Synthesis and characterization of vanadium-doped $\mathrm{LiMnPO}_{4}$-compounds $\left(\mathrm{LiMnPO}_{4}\right)_{\mathrm{x}}\left(\mathrm{VO}_{4}\right)_{1-\mathrm{x}}(0.8<\mathrm{x}<1)$. Chem. Mater. 2012, 24, 4717-4724.

160. Hong, J.; Wang, C.S.; Chen, X.; Upretim, S.; Whittingham, M.S. Vanadium modified $\mathrm{LiFePO}_{4}$ cathode for Li-ion batteries and energy storage. Electrochem. Solid-State Lett. 2009, 12, A33-A38. [CrossRef]

161. Dai, E.R.; Fang, H.S.; Yang, B.; Ma, W.H.; Dai, Y.N. Synthesis of vanadium doped $\mathrm{LiMnPO}_{4}$ by an improved solid-state method. Ceram. Int. 2015, 41, 8171-8176. [CrossRef]

162. Chen, L.B.; Zhang, M.; Wei, W.F. Graphene-based composites as cathode materials for lithium-ion batteries. J. Nanomater. 2013, 2013, 940389. [CrossRef]

163. Jiang, Y.; Liu, R.Z.; Xu, W.W.; Jiao, Z.; Wu, M.H.; Chu, Y.L.; Su, L.; Cao, H.; Hou, M.; Zhao, B. A novel graphene modified $\mathrm{LiMnPO}_{4}$ as a performance-improved cathode material for lithium-ion batteries. J. Mater. Res. 2013, 28, 2584-2589. [CrossRef]

164. Zong, J.; Liu, X.J. Graphene nanoplates structured $\mathrm{LiMnPO}_{4} / \mathrm{C}$ composite for lithium-ion battery. Electrochim. Acta 2014, 116, 9-18. [CrossRef]

165. Fu, X.; Chang, K.; Li, B.; Tang, H.; Shangguan, E.; Chang, Z. Low-temperature synthesis of $\mathrm{LiMnPO}_{4} / \mathrm{RGO}$ cathode material with excellent voltage platform and cycle performance. Electrochim. Acta 2017, 225, $272-282$. [CrossRef]

166. Kopek, M.; Yamada, A.; Kobayashi, G.; Nishimura, S.; Kanno, R.; Mauger, A.; Gendron, F.; Julien, C.M. Structural and magnetic properties of $\mathrm{Li}_{\mathrm{x}}\left(\mathrm{Mn}_{\mathrm{y}} \mathrm{Fe}_{1-\mathrm{y}}\right) \mathrm{PO}_{4}$ electrode materials for Li-ion batteries. J. Power Sources 2009, 189, 1154-1163. [CrossRef]

167. Oh, S.M.; Jung, H.G.; Yoon, C.S.; Myung, S.T.; Chen, Z.H.; Amine, K.; Sun, Y.K. Enhanced electrochemical performance of carbon-LiMn ${ }_{1-x} \mathrm{Fe}_{x} \mathrm{PO}_{4}$ nanocomposite cathode for lithium-ion batteries. J. Power Sources 2011, 196, 6924-6928. [CrossRef]

168. Tan, Z.; Gao, P.; Cheng, F.; Luo, H.; Chen, J.; Zhou, H.; Tan, S. High power performance of multicomponent olivine cathode material for lithium-ion batteries. Funct. Mater. Lett. 2011, 4, 293-299. [CrossRef]

169. Wang, H.L.; Yang, Y.; Liang, Y.Y.; Cui, L.F.; Casalongue, H.S.; Li, Y.G.; Hong, G.S.; Cui, Y.; Dai, H.J. $\mathrm{LiMn}_{1-x} \mathrm{Fe}_{x} \mathrm{PO}_{4}$ nanorods grown on graphene sheets for ultrahigh-rate-performance lithium ion batteries. Angew. Chem. Int. Ed. 2011, 50, 7364-7368. [CrossRef] [PubMed]

170. Saravanan, K.; Ramar, V.; Balaya, P.; Vittal, J.J. Li $\left(\mathrm{Mn}_{x} \mathrm{Fe}_{1-\mathrm{x}}\right) \mathrm{PO}_{4} / \mathrm{C}(x=0.5,0.75$ and 1) nanoplates for lithium storage application. J. Mater. Chem. 2011, 21, 14925-14935. [CrossRef]

171. Von Hagen, R.; Lorrmann, H.; Moller, K.C.; Mathur, S. Electrospun $\mathrm{LiFe}_{1-y} \mathrm{Mn}_{\mathrm{y}} \mathrm{PO}_{4} / \mathrm{C}$ nanofiber composites as self-supporting cathodes in Li-ion batteries. Adv. Energy Mater. 2012, 2, 553-559. [CrossRef]

172. Hong, Y.; Tang, Z.; Hong, Z.; Zhang, Z. $\mathrm{LiMn}_{1-x} \mathrm{Fe}_{x} \mathrm{PO}_{4}(x=0,0.1,0.2)$ nanorods synthesized by a facile solvothermal approach as high performance cathode materials for lithium-ion batteries. J. Power Sources 2014, 248, 655-659. [CrossRef]

173. Hu, L.; Qiu, B.; Xia, Y.G.; Qin, Z.H.; Qin, L.F.; Zhou, X.F.; Liu, Z.P. Solvothermal synthesis of Fe-doping $\mathrm{LiMnPO}_{4}$ nanomaterials for Li-ion batteries. J. Power Sources 2014, 248, 246-252. [CrossRef]

174. Seo, I.; Senthilkumar, B.; Kim, K.H.; Kim, J.K.; Kim, Y.; Ahn, J.H. Atomic structural and electrochemical impact of Fe substitution on nano porous $\mathrm{LiMnPO}_{4}$. J. Power Sources 2016, 320, 59-67. [CrossRef]

175. Jo, M.; Yoo, H.; Jung, Y.S.; Cho, J. Carbon-coated nanoclustered $\mathrm{LiMn}_{0.71} \mathrm{Fe}_{0.29} \mathrm{PO}_{4}$ cathode for lithium-ion batteries. J. Power Sources 2012, 216, 162-168. [CrossRef] 
176. Wang, K.; Hou, M.Y.; Yuan, S.Y.; Yu, H.C.; Wang, Y.G.; Wang, C.X.; Xia, Y.Y. An additional discharge plateau of $\mathrm{Mn}^{3+}$ in $\mathrm{LiFe}_{0.5} \mathrm{Mn}_{0.5} \mathrm{PO}_{4}$ at high current rates. Electrochem. Commun. 2015, 55, 6-9. [CrossRef]

177. Yan, S.Y.; Wang, C.Y.; Gu, R.M.; Sun, S.; Li, M.W. Synergetic Fe substitution and carbon connection in $\mathrm{LiMn}_{1-x} \mathrm{Fe}_{x} \mathrm{PO}_{4} / \mathrm{C}$ cathode materials for enhanced electrochemical performances. J. Alloy. Compd. 2015, 628, 471-479. [CrossRef]

178. Yan, S.Y.; Wang, C.Y.; Gu, R.M.; Li, M.W. Enhanced kinetic behaviors of $\mathrm{LiFe}_{0.5} \mathrm{Mn}_{0.5} \mathrm{PO}_{4} / \mathrm{C}$ cathode material by Fe substitution and carbon coating. J. Solid State Electrochem. 2015, 19, 2943-2950. [CrossRef]

179. Xiang, W.; Wang, E.H.; Chen, M.Z.; Shen, H.H.; Chou, S.L.; Chen, H.; Guo, X.D.; Zhong, B.H.; Wang, X.L. Hierarchical structured $\mathrm{LiFe}_{0.5} \mathrm{Mn}_{0.5} \mathrm{PO}_{4}$ spheres synthesized by template-engaged reaction as cathodes for high power Li-ion batteries. Electrochim. Acta 2015, 178, 353-360. [CrossRef]

180. Liu, W.; Gao, P.; Mi, Y.; Chen, J.; Zhou, H.; Zhang, X. Fabrication of high tap density $\mathrm{LiFe}_{0.6} \mathrm{Mn}_{0.4} \mathrm{PO}_{4} / \mathrm{C}$ microspheres by a double carbon coating-spray drying method for high rate lithium ion batteries. J. Mater. Chem. A 2013, 1, 2411-2417. [CrossRef]

181. Nie, P.; Shen, L.F.; Zhang, F.; Chen, L.; Deng, H.F.; Zhang, X.G. Flower-like $\mathrm{LiMnPO}_{4}$ hierarchical microstructures assembled from single-crystalline nanosheets for lithium-ion batteries. CrystEngComm 2012, 14, 4284-4288. [CrossRef]

182. Pan, X.L.; Xu, C.Y.; Zhen, L. Synthesis of $\mathrm{LiMnPO}_{4}$ microspheres assembled by plates, wedges and prisms with different crystallographic orientations and their electrochemical performance. CrystEngComm 2012, 14, 6412-6418. [CrossRef]

183. Oh, S.M.; Myung, S.T.; Park, J.B.; Scrosati, B.; Amine, K.; Sun, Y.K. Double-structured $\operatorname{LiMn}_{0.85} \mathrm{Fe}_{0.15} \mathrm{PO}_{4}$ coordinated with $\mathrm{LiFePO}_{4}$ for rechargeable lithium batteries. Angew. Chem. Int. Ed. 2012, 51, 1853-1856. [CrossRef] [PubMed]

184. Liu, L.; Chen, G.; Du, B.; Cui, Y.; Ke, X.; Liu, J.; Guo, Z.; Shi, Z.; Zhang, H.; Chou, S. Nano-sized cathode material $\mathrm{LiMn}_{0.6} \mathrm{Fe}_{0.4} \mathrm{PO}_{4} / \mathrm{C}$ synthesized via improved sol-gel routine and its magnetic and electrochemical properties. Electrochim. Acta 2017, 255, 205-211. [CrossRef]

185. Yang, L.; Xia, Y.; Fan, X.; Qin, L.; Qiu, B.; Liu, Z. Constructing durable carbon layer on $\mathrm{LiMn}_{0.8} \mathrm{Fe}_{0.2} \mathrm{PO}_{4}$ with superior long-term cycling performance for lithium-ion battery. Electrochim. Acta 2016, 191, 200-206. [CrossRef]

186. Zhou, X.; Xie, Y.; Deng, Y.; Qin, X.; Chen, G. The enhanced rate performance of $\mathrm{LiMn}_{0.5} \mathrm{Fe}_{0.5} \mathrm{PO}_{4} / \mathrm{C}$ cathode material via synergistic strategies of surfactant-assisted solid state method and carbon coating. J. Mater. Chem. A 2015, 3, 996-1004. [CrossRef]

187. Mi, Y.; Gao, P.; Liu, W.; Zhang, W.; Zhou, H. Carbon nanotube-loaded mesoporous $\mathrm{LiFe}_{0.6} \mathrm{Mn}_{0.4} \mathrm{PO}_{4} / \mathrm{C}$ microspheres as high performance cathodes for lithium-ion batteries. J. Power Sources 2014, 267, 459-468. [CrossRef]

188. Duan, J.; Hu, G.; Cao, Y.; Du, K.; Peng, Z. Synthesis of high-performance Fe-Mg co-doped $\mathrm{LiMnPO}_{4} / \mathrm{C}$ via a mechano-chemical liquid-phase activation technique. Ionics 2016, 22, 609-619. [CrossRef]

189. Liu, S.; Fang, H.; Dai, E.; Yang, B.; Yao, Y.; Ma, W.; Dai, Y. Effect of carbon content on properties of $\mathrm{LiMn}_{0.8} \mathrm{Fe}_{0.19} \mathrm{Mg}_{0.01} \mathrm{PO}_{4} / \mathrm{C}$ composite cathode for lithium ion batteries. Electrochim. Acta 2014, 116, 97-102. [CrossRef]

190. Liu, S.; Fang, H.; Yang, B.; Yao, Y.; Ma, W.; Dai, Y. Improving rate performance of $\mathrm{LiMnPO}_{4}$ based material by forming electron-conducting iron phosphides. J. Power Sources 2013, 230, 267-270. [CrossRef]

191. Kisu, K.; Iwama, E.; Onishi, W.; Nakashima, S.; Naoi, W.; Naoi, K. Ultrafast nano-spherical single-crystalline LiMn $0.792 \mathrm{Fe}_{0.198} \mathrm{Mg}_{0.010} \mathrm{PO}_{4}$ solid-solution confined among unbundled interstices of SGCNTs. J. Mater. Chem. A 2014, 2, 20789-20798. [CrossRef]

192. Ramar, V.; Balaya, P. Enhancing the electrochemical kinetics of high voltage olivine $\mathrm{LiMnPO}_{4}$ by isovalent co-doping. Phys. Chem. Chem. Phys. 2013, 15, 17240-17249. [CrossRef] [PubMed]

193. Jang, D.; Palanisamy, K.; Yoon, J.; Kim, Y.; Yoon, W.S. Crystal and local structure studies of $\mathrm{LiFe}_{0.48} \mathrm{Mn}_{0.48} \mathrm{Mg}_{0.04} \mathrm{PO}_{4}$ cathode material for lithium rechargeable batteries. J. Power Sources 2013, 244, 581-585. [CrossRef]

194. Yi, H.; Hu, C.; Fang, H.; Yang, B.; Yao, Y.; Ma, W.; Dai, Y. Electrochemical performance of $\mathrm{LiMn}_{0.9} \mathrm{Fe}_{0.09} \mathrm{Mg}_{0.01} \mathrm{PO}_{4} / \mathrm{C}$ synthesized under vacuum condition. Int. J. Electrochem. Sci. 2012, 7, 663-670.

195. Fang, H.; Dai, E.; Yang, B.; Yao, Y.; Ma, W. $\mathrm{LiMn}_{0.8} \mathrm{Fe}_{0.19} \mathrm{Mg}_{0.01} \mathrm{PO}_{4} / \mathrm{C}$ as a high performance cathode material for lithium ion batteries. J. Power Sources 2012, 204, 193-196. [CrossRef] 
196. Yi, H.; Hu, C.; Fang, H.; Yang, B.; Yao, Y.; Ma, W.; Dai, Y. Optimized electrochemical performance of $\mathrm{LiMn}_{0.9} \mathrm{Fe}_{0.1-\mathrm{x}} \mathrm{Mg}_{\mathrm{x}} \mathrm{PO}_{4} / \mathrm{C}$ for lithium ion batteries. Electrochim. Acta 2011, 56, 4052-4057. [CrossRef]

197. Kim, J.; Park, Y.U.; Seo, D.H.; Kim, J.; Kim, S.W.; Kang, K. Mg and Fe Co-doped Mn based olivine cathode material for high power capability. J. Electrochem. Soc. 2011, 158, A250-A254. [CrossRef]

198. Hu, C.; Yi, H.; Fang, H.; Yang, B.; Yao, Y.; Ma, W.; Dai, Y. Improving the electrochemical activity of $\mathrm{LiMnPO}_{4}$ via Mn-site co-substitution with Fe and Mg. Electrochem. Commun. 2010, 12, 1784-1787. [CrossRef]

199. Sronsri, C.; Noisong, P.; Danvirutai, C. Synthesis, characterization and vibrational spectroscopic study of Co, Mg co-doped LiMnPO 4 . Spectrochim. Acta A 2016, 153, 436-444. [CrossRef] [PubMed]

200. Xiang, W.; Zhong, Y.; Tang, Y.; Shen, H.; Wang, E.; Liu, H.; Zhong, B.; Guo, X. Improving the electrochemical kinetics of lithium manganese phosphate via co-substitution with iron and cobalt. J. Alloy. Compd. 2015, 635, 180-187. [CrossRef]

201. Huang, Q.Y.; Wu, Z.; Su, J.; Long, Y.F.; Lv, X.Y.; Wen, Y.X. Synthesis and electrochemical performance of Ti-Fe co-doped $\mathrm{LiMnPO}_{4} / \mathrm{C}$ as cathode material for lithium-ion batteries. Ceram. Int. 2016, 42, 11348-11354. [CrossRef]

202. Jung, Y.H.; Park, W.B.; Pyo, M.; Sohn, K.S.; Ahn, D. A multi-element doping design for a high performance $\mathrm{LiMnPO}_{4}$ cathode via metaheuristic computation. J. Mater. Chem A 2017, 5, 8939-8945. [CrossRef]

203. Qin, L.; Xia, Y.; Cao, H.; Yang, L.; Liu, Z. Synthesis and electrochemical performance of $\mathrm{LiMn}_{\mathrm{x}} \mathrm{Fe}_{\mathrm{y}}(\mathrm{V} \square)_{1-\mathrm{x}-\mathrm{y}} \mathrm{PO}_{4}$ cathode materials for lithium-ion batteries. Electrochim. Acta 2016, 222, 1660-1667. [CrossRef]

204. Di Lecce, D.; Hassoun, J. Lithium transport properties in $\mathrm{LiMn}_{1-x} \mathrm{Fe}_{x} \mathrm{PO}_{4}$ olivine cathodes. J. Phys. Chem. C 2015, 119, 20855-20863. [CrossRef]

205. Zaghib, K.; Trudeau, M.; Guerfi, A.; Trottier, J.; Mauger, A.; Veillette, R.; Julien, C.M. New advanced cathode material: $\mathrm{LiMnPO}_{4}$ encapsulated with $\mathrm{LiFePO}_{4}$. J. Power Sources 2012, 204, 177-181. [CrossRef]

206. Xu, X.; Wang, T.; Bi, Y.; Liu, M.; Yang, W.; Peng, Z.; Wang, D. Improvement of electrochemical activity of $\mathrm{LiMnPO}_{4}$-based cathode by surface iron enrichment. J. Power Sources 2017, 341, 175-182. [CrossRef]

207. Shi, J.; Wang, Z.; Fu, Y.Q. Density functional theory study of lithium diffusion at the interface between olivine-type $\mathrm{LiFePO}_{4}$ and $\mathrm{LiMnPO}_{4}$. J. Phys. D Appl. Phys. 2016, 49, 505601. [CrossRef]

208. Guorong, H.; Yanbing, C.; Zhongdong, P.; Ke, D.; Zhijian, Z.; Min, L. Method for modifying nanometer $\mathrm{LiMnPO}_{4} / \mathrm{C}$ cathode material coated with lithium ion conductor. Chinese Patent CN 201510845237, 26 November 2015.

209. Zhang, B.; Wang, X.W.; Zhang, J.F. Novel synthesis of $\mathrm{LiMnPO}_{4} @ \mathrm{Li}_{3} \mathrm{~V}_{2}\left(\mathrm{PO}_{4}\right)_{3} / \mathrm{C}$ composite cathode material. RSC Adv. 2014, 4, 49123-49127. [CrossRef]

210. Strobridge, F.C.; Clément, R.J.; Leskes, M.; Middlemiss, D.S.; Borkiewicz, O.J.; Wiaderek, K.M.; Chapman, K.W.; Chupas, P.J.; Grey, C.P. Identifying the structure of the intermediate, $\mathrm{Li}_{2 / 3} \mathrm{CoPO}_{4}$, formed during electrochemical cycling of $\mathrm{LiCoPO}_{4}$. Chem. Mater. 2014, 26, 6193-6205. [CrossRef] [PubMed]

211. Mauger, A.; Julien, C.M.; Armand, M.; Goodenough, J.B.; Zaghib, K. Li(Ni,Co)PO $\mathrm{PO}_{4}$ as cathode materials for lithium batteries: Will the dream come true? Curr. Opin. Electrochem. 2017, 6, 63-69. [CrossRef]

212. Markevich, E.; Sharabi, R.; Gottlieb, H.; Borgel, V.; Fridman, K.; Salitra, G.; Aurbach, D.; Semrau, G.; Schmidt, M.A.; Schall, N.; et al. Reasons for capacity fading of $\mathrm{LiCoPO}_{4}$ cathodes in $\mathrm{LiPF} 6$ containing electrolyte solutions. Electrochem. Commun. 2012, 15, 22-25. [CrossRef]

213. Wu, B.R.; Xu, H.L.; Mu, D.B.; Shi, L.L.; Jiang, B.; Gai, L.; Wang, L.; Liu, Q.; Ben, L.B.; Wu, F. Controlled solvothermal synthesis and electrochemical performance of $\mathrm{LiCoPO}_{4}$ submicron single crystals as a cathode material for lithium ion batteries. J. Power Sources 2016, 304, 181-188. [CrossRef]

214. Truong, Q.D.; Devaraju, M.K.; Ganbe, Y.; Tomai, T.; Honma, I. Controlling the shape of $\mathrm{LiCoPO}_{4}$ nanocrystals by supercritical fluid process for enhanced energy storage properties. Sci. Rep. 2014, 4, 3975-3983. [CrossRef] [PubMed]

215. Tussupbayev, R.; Taniguchi, I. Physical and electrochemical properties of $\mathrm{LiCoPO}_{4} / \mathrm{C}$ nanocomposites prepared by a combination of emulsion drip combustion and wet ball-milling followed by heat treatment. J. Power Sources 2013, 236, 276-284. [CrossRef]

216. Ludwig, J.; Nordlund, D.; Doeff, M.M.; Nilges, T. Synthesis and characterization of metastable, $20 \mathrm{~nm}$-sized Pna21-LiCoPO 4 nanospheres. J. Solid State Chem. 2017, 248, 9-17. [CrossRef] 
217. Maeyoshi, Y.; Miyamoto, S.; Noda, Y.; Munakata, H.; Kanamura, K. Effect of organic additives on characteristics of carbon-coated $\mathrm{LiCoPO}_{4}$ synthesized by hydrothermal method. J. Power Sources 2017, 337, 92-99. [CrossRef]

218. Ornek, A. A new and effective approach to $4.8 \mathrm{~V}$ cathode synthesis with superior electrochemical qualities for lithium-ion applications. J. Alloy. Compd. 2017, 710, 809-818. [CrossRef]

219. Laszczynski, N.; Birrozzi, A.; Maranski, K.; Copley, M.; Schuster, M.E.; Passerini, S. Effect of coatings on the green electrode processing and cycling behaviour of $\mathrm{LiCoPO}_{4}$. J. Mater. Chem. A 2016, 4, 17121-17128. [CrossRef]

220. Ni, J.F.; Gao, L.J.; Lu, L. Carbon coated lithium cobalt phosphate for Li-ion batteries: Comparison of three coating techniques. J. Power Sources 2013, 221, 35-41. [CrossRef]

221. Prabu, M.; Selvasekarapandian, S.; Reddy, M.V.; Chowdari, B.V.R. Impedance studies on the 5-V cathode material, $\mathrm{LiCoPO}_{4}$. J. Solid State Electrochem. 2012, 16, 1833-1839. [CrossRef]

222. Wang, F.; Yang, J.; Li, Y.N.; Wang, J. Novel hedgehog-like $5 \mathrm{~V} \mathrm{LiCoPO}_{4}$ positive electrode material for rechargeable lithium battery. J. Power Sources 2011, 196, 4806-4810. [CrossRef]

223. Yamada, Y.; Noda, Y.; Munakata, H.; Yoshida, S.; Shibata, D.; Kanamura, K. Investigation of carbon-coating effect on the electrochemical performance of $\mathrm{LiCoPO}_{4}$ single particle. Electrochemistry 2018, 86, 145-151. [CrossRef]

224. Wang, Y.; Qiu, J.; Yu, Z.; Ming, H.; Li, M.; Zhang, S.; Yang, Y. $\mathrm{AlF}_{3}$-modified $\mathrm{LiCoPO}_{4}$ for an advanced cathode towards high energy lithium-ion battery. Ceram. Int. 2018, 44, 1312-1320. [CrossRef]

225. Zhao, H.; Yu, Y.; Wang, G.; Chen, Y.; Liu, X. Synthesis of nanosphere-like $\mathrm{LiCoPO}_{4}$ with excellent electrochemical performance via micro reactor assisted co-precipitation method. Funct. Mater. Lett. 2018. [CrossRef]

226. Kreder, K.J.; Manthiram, A. Vanadium-substituted $\mathrm{LiCoPO}_{4}$ core with a monolithic $\mathrm{LiFePO}_{4}$ shell for high-voltage lithium-ion batteries. ACS Energy Lett. 2017, 2, 64-69. [CrossRef]

227. Jang, I.C.; Son, C.G.; Yang, S.M.G.; Lee, J.W.; Cho, A.R.; Aravindan, V.; Park, G.J.; Kang, K.S.; Kim, W.S.; Cho, W.I.; et al. $\mathrm{LiFePO}_{4}$ modified $\mathrm{Li}_{1.02}\left(\mathrm{Co}_{0.9} \mathrm{Fe}_{0.1}\right)_{0.98} \mathrm{PO}_{4}$ cathodes with improved lithium storage properties. J. Mater. Chem. 2011, 21, 6510-6515. [CrossRef]

228. Kosova, N.V.; Podgornova, O.A.; Devyatkina, E.T.; Podugolnikov, V.R.; Petrov, S.A. Effect of Fe ${ }^{2+}$ substitution on the structure and electrochemistry of $\mathrm{LiCoPO}_{4}$ prepared by mechanochemically assisted carbothermal reduction. J. Mater. Chem. A 2014, 2, 20697-20705. [CrossRef]

229. Allen, J.L.; Thompson, T.; Delp, S.A.; Wolfenstine, J.; Jow, T.R. Cr and Si substituted-LiCo ${ }_{0.9} \mathrm{Fe}_{0.1} \mathrm{PO}_{4}$ : Structure, full and half Li-ion cell performance. J. Power Sources 2016, 327, 229-234. [CrossRef]

230. Hanafusa, R.; Oka, Y.; Nakamura, T. Electrochemical and magnetic studies of Li-deficient $\operatorname{Li}_{1-x} \mathrm{Co}_{1-x} \mathrm{Fe}_{\mathrm{x}} \mathrm{PO}_{4}$ olivine cathode compounds. J. Electrochem. Soc. 2014, 162, A3045-A3051. [CrossRef]

231. Kang, Y.M.; Kim, Y.I.; Oh, M.W.; Yin, R.Z.; Lee, Y.; Han, D.W.; Kwon, H.S.; Kim, J.H.; Ramanath, G. Structurally stabilized olivine lithium phosphate cathodes with enhanced electrochemical properties through Fe doping. Energy Environ. Sci. 2011, 4, 4978-4983. [CrossRef]

232. Brutti, S.; Manzi, J.; Meggiolaro, D.; Vitucci, F.M.; Trequattrini, F.; Paolone, A.; Palumbo, O. Interplay between local structure and transport properties in iron-doped $\mathrm{LiCoPO}_{4}$ olivines. J. Mater. Chem. A 2017, 5, 14020-14030. [CrossRef]

233. Ni, J.F.; Han, Y.; Liu, J.; Wang, H.; Gao, L. Improving electrochemical properties of $\mathrm{LiCoPO}_{4}$ by $\mathrm{Mn}$ substitution: A case research on $\mathrm{LiCo}_{0.5} \mathrm{Mn}_{0.5} \mathrm{PO}_{4}$. ECS Electrochem. Lett. 2012, 2, A3-A5. [CrossRef]

234. Allen, J.L.; Thompson, T.; Sakamoto, J.; Becker, C.R.; Jow, T.R.; Wolfenstine, J. Transport properties of $\mathrm{LiCoPO}_{4}$ and Fe-substituted $\mathrm{LiCoPO}_{4}$. J. Power Sources 2014, 254, 204-208. [CrossRef]

235. Dimesso, L.; Spanheimer, C.; Jaegermann, W. Influence of isovalent ions (Ca and Mg) on the properties of $\mathrm{LiCo}_{0.9} \mathrm{M}_{0.1} \mathrm{PO}_{4}$ powders. J. Power Sources 2013, 243, 668-675. [CrossRef]

236. Dimesso, L.; Spanheimer, C.; Jaegermann, W. Investigation of the $\mathrm{LiCo}_{1-x} \mathrm{Mg}_{x} \mathrm{PO}_{4}(0 \leq \mathrm{x} \leq 0.1)$ system. J. Alloy. Compd. 2014, 582, 69-74. [CrossRef]

237. Dimesso, L.; Spanheimer, C.; Mueller, M.M.; Kleebe, H.J.; Jaegermann, W. Properties of Ca-containing $\mathrm{LiCoPO}_{4}$-graphitic carbon foam composites. Ionics 2015, 21, 2101-2107. [CrossRef]

238. Kreder, K.J.; Assat, G.; Manthiram, A. Aliovalent substitution of $\mathrm{V}^{3+}$ for $\mathrm{Co}^{2+}$ in $\mathrm{LiCoPO}_{4}$ by a low-temperature microwave-assisted solvothermal process. Chem. Mater. 2016, 28, 1847-1853. [CrossRef] 
239. Li, H.; Wang, Y.; Yang, X.; Liu, L.; Chen, L.; Wei, J. Improved electrochemical performance of $5 \mathrm{~V} \mathrm{LiCoPO}_{4}$ cathode materials via yttrium doping. Solid State Ion. 2014, 255, 84-88. [CrossRef]

240. Wolfenstine, J. Electrical conductivity of doped $\mathrm{LiCoPO}_{4}$. J. Power Sources 2006, 158, 1431-1435. [CrossRef]

241. Wang, Y.; Chen, J.; Qiu, J.; Yu, Z.; Ming, H.; Li, M.; Zhang, S.; Yang, Y. Cr-substituted LiCoPO 4 core with a conductive carbon layer towards high-voltage lithium-ion batteries. J. Solid State Chem. 2018, 258, 32-41. [CrossRef]

242. Amin, R.; Lin, C.; Peng, J.; Weichert, K.; Acartürk, T.; Starke, U.; Maier, J. Silicon-doped $\mathrm{LiFePO}_{4}$ single crystals: Growth, conductivity behavior, and diffusivity. Adv. Funct. Mater. 2009, 19, 1697-1704. [CrossRef]

243. Liu, D.; Zhu, W.; Kim, C.; Cho, M.; Guerfi, A.; Delp, S.A.; Allen, J.L.; Jow, T.R.; Zaghib, K. High-energy lithium-ion battery using substituted $\mathrm{LiCoPO}_{4}$ : From coin type to 1 Ah cell. J. Power Sources 2018, 388, 52-56. [CrossRef]

244. Cherkashinin, G.; Eilhardt, R.; Lebedev, M.V.; Nappini, S.; Magnano, E.; Jaegermann, W. Olivine-LiNiPO 4 thin films: Chemical compatibility with liquid electrolyte and interface stability at high potential. J. Electrochem. Soc. 2018, 165, H3143-H3147. [CrossRef]

245. Örnek, A. Positive effects of a particular type of microwave-assisted methodology on the electrochemical properties of olivine $\mathrm{LiMPO}_{4}(\mathrm{M}=\mathrm{Fe}$, Co and Ni) cathode materials. Chem. Eng. J. 2018, 331, 501-509. [CrossRef]

246. Devi, L.S.; Babu, K.V.; Madhavilatha, B.; Reddi, M.S.; Samatha, K.; Veeraiah, V. Structural and electrochemical characterizations of nanostructured olivine $\mathrm{LiNi}_{1-x} \mathrm{Co}_{x} \mathrm{PO}_{4}(x=0$ and 0.5$)$ cathode materials for lithium-ion batteries. S. Afr. J. Chem. Eng. 2018, 25, 42-47.

247. Karthikprabhu, S.; Karuppasamy, K.; Vikraman, D.; Prasanna, K.; Maiyalagan, T.; Nichelson, A.; Kathalingam, A.; Kim, H.-S. Electrochemical performances of $\mathrm{LiNi}_{1-x} \mathrm{Mn}_{x} \mathrm{PO}_{4}(\mathrm{x}=0.05-0.2)$ olivine cathode materials for high voltage rechargeable lithium ion batteries. Appl. Surf. Sci. 2018, 449, 435-444. [CrossRef]

(C) 2018 by the authors. Licensee MDPI, Basel, Switzerland. This article is an open access article distributed under the terms and conditions of the Creative Commons Attribution (CC BY) license (http:/ / creativecommons.org/licenses/by/4.0/). 